\title{
Flora do Ceará: Turneraceae
}

\author{
Flora of Ceará: Turneraceae
}

\author{
Lamarck Rocha $^{1,4}$, José Walter Araújo Nogueira ${ }^{2}$, Marlene Feliciano Figueiredo ${ }^{2}$ \\ \& Maria Iracema Bezerra Loiola ${ }^{3}$
}

\begin{abstract}
Resumo
É apresentado o levantamento florístico da família Turneraceae no estado do Ceará, Brasil. Foram reconhecidos dois gêneros e 22 espécies: Piriqueta com sete espécies e Turnera com 15, das quais Turnera reginae é uma nova ocorrência. De modo geral, as espécies apresentam ampla distribuição, sendo frequentemente encontradas na vegetação da caatinga, carrasco, cerrado, floresta ombrófila e tabuleiros litorâneos, associandose principalmente a áreas abertas e antropizadas. São apresentadas fotografias, chaves, descrições, comentários gerais e mapas de distribuição das espécies no Ceará.
\end{abstract}

Palavras-chave: florística, Piriqueta, Região Nordeste, Turnera.

\begin{abstract}
A floristic survey of Turneraceae from Ceará state, Brazil, is presented. Two genera and 22 species were recognized: Piriqueta with seven species and Turnera with 15, of which Turnera reginae is a new occurrence. In general, the species are widely distributed and are often found in caatinga, carrasco, cerrado, ombrophilous forest and tabuleiros litorâneos vegetation, associated mainly with open and disturbed areas. Photographs, keys, descriptions, general comments and distribution maps of the species found in Ceará are provided.
\end{abstract}

Key words: floristics, Piriqueta, Northeast Brazil, Turnera.

\section{Introdução}

Turneraceae inclui 12 gêneros e 229 espécies, distribuídas nas regiões tropicais e subtropicais da América e África. No continente africano ocorrem nove gêneros e 40 espécies, algumas delas endêmicas de Madagascar e nas Ilhas Mascarenhas (Arbo 2007). Nas Américas a diversidade específica é maior, sendo reconhecidas 188 espécies pertencentes a quatro gêneros: Adenoa Arbo, Erblichia Seem., Piriqueta Aubl. e Turnera L. (Arbo 2007; Thulin et al. 2012). No Brasil, Turneraceae está representada pelos gêneros Piriqueta e Turnera, totalizando 158 espécies, das quais 111 são endêmicas e 48 raras (Arbo \& Giulietti 2009; BFG 2015).
Turneraceae, juntamente com Malesherbiaceae e Passifloraceae s.s., está situada em Passifloraceae s.l. na ordem Malpighiales (APG IV 2016), mas filogenias com ampla amostragem ainda sustentam as três famílias como independentes (Thulin et al. 2012; Tokuoka 2012), assim como consta em Cronquist (1981), além de outros sistemas de classificação tradicionais. Dessa maneira, neste estudo, adotamos a classificação deste último autor.

As Turneraceae são, de modo geral, subarbustos ou ervas com folhas simples, alternas, margens recortadas, frequentemente apresentando um par de nectários basilaminares ou peciolares. As flores são bissexuadas, geralmente heterostilas,

\footnotetext{
${ }^{1}$ Universidade Estadual de Feira de Santana, Prog. Pós-graduação em Botânica, Av. Universitária s/n, 44031-460, Feira de Santana, BA, Brasil.

${ }^{2}$ Universidade Estadual Vale do Acaraú, Centro de Ciências Agrárias e Biológicas, Av. da Universidade 850, 62040-370, Sobral, CE, Brasil.

${ }^{3}$ Universidade Federal do Ceará, Depto. Biologia, Herbário Prisco Bezerra, Campus do Pici, bl. 906, 60455-970, Fortaleza, CE, Brasil.

${ }^{4}$ Autor para correspondência: lamarck_rocha@hotmail.com
} 
actinomorfas e pentâmeras, com exceção do gineceu, que apresenta um ovário unilocular, com três placentas parietais e três estiletes. Os frutos são cápsulas loculicidas, 3-valvares e as sementes são geralmente reticuladas (Arbo 2007).

Algumas espécies de Turneraceae são conhecidas por serem ervas daninhas e invasoras de culturas, como Turnera subulata Sm.; outras espécies, entretanto, têm potencial medicinal, a exemplo de $T$. diffusa Willd. ex Schult., que é usada como analgésico, energético e afrodisíaco na América Central (Arbo 2000). No Nordeste brasileiro, as raízes de T. subulata são utilizadas no tratamento de diabetes, e T. melochioides Cambess. é empregada como emplasto, para o tratamento de inflamações dérmicas (Braga 2001).

A taxonomia dos gêneros americanos de Turneraceae tem sido amplamente estudada (Arbo 1977, 1979, 1995, 1997, 2000, 2005, 2008). No Brasil, o conhecimento sobre a família está associado principalmente a floras locais e estaduais (e.g., Arbo \& Silva 2005; Arbo 2006a, 2009, 2013; Rocha et al. 2012, 2017; Rocha \& Rapini 2016). Para o estado do Ceará, entretanto, as informações sobre o grupo eram escassas, restritas a checklists (Arbo 2006b). Portanto, com a finalidade de contribuir com o projeto "Flora do Ceará", objetivamos inventariar as Turneraceae deste estado, provendo descrições, chaves de identificação, fotografias e dados atualizados sobre a distribuição geográfica das espécies.

\section{Material e Métodos}

O estudo se baseou na análise de espécimes obtidos em campo bem como, das coleções dos herbários ALCB, CEN, CEPEC, CTES, EAC, ESA, HRB, HUEFS, HUVA, HVASF, IPA, MBM, R, RB, SPF, UEC, UFRN, além das coleções online dos herbários K, F, M e P (acrônimos conforme Thiers, continuamente atualizado).

As identificações foram realizadas através de consulta às revisões de Arbo (1995, 1997, 2000, $2005,2008)$. Os nomes dos autores e espécies foram checados no IPNI (continuamente atualizado). A caracterização das estruturas vegetativas e reprodutivas se baseou principalmente em Radford et al. (1974) e Harris \& Harris (2000); para os tipos de indumento, seguiu-se Payne (1978) e Gonzalez \& Arbo (2004). Os comentários sobre a distribuição geográfica das espécies, sua ocorrência no estado, aspectos ecológicos, preferência de habitats, floração e frutificação se basearam em informações de campo, etiquetas de herbário e literatura especializada.
Os mapas de distribuição foram confeccionados no programa DIVA-GIS 7.5 (Hijmans et al. 2017) conforme as coordenadas disponíveis nas etiquetas de herbário; na ausência dessas informações, as coordenadas das localidades de coleta foram obtidas através da ferramenta GeoLoc (CRIA 2005). Para a organização do estudo, seguiu-se o padrão apresentado nas demais monografias sobre a flora do Ceará (e.g., Menezes et al. 2013; Soares-Neto et al. 2014a,b; Capistrano \& Loiola 2015).

\section{Resultados e Discussão}

Para o estado do Ceará foram registradas 22 espécies distribuídas em dois gêneros: Piriqueta (sete) e Turnera (15). De modo geral, as espécies apresentam ampla distribuição, ocorrendo preferencialmente na vegetação da caatinga, associadas a áreas abertas e ensolaradas, às vezes antropizadas, como margens de estradas ou trilhas. Florescem e frutificam durante o ano todo.

Neste estudo, os espécimes com localidades incertas não foram incluídos: Turnera dichotoma Gardner, A. Castellanos 33415 (UEC), referida para Barbalha, é endêmica de Minas Gerais, provavelmente a localidade foi incorretamente indicada (Arbo 2008).

\section{Tratamento taxonômico}

Turneraceae Kunth ex DC., Prodr. 3: 345. 1828. nom. cons.

Ervas, subarbustos ou arbustos. Folhas pecioladas ou subsésseis, alternas, simples, geralmente pilosas, nervação broquidódroma, margens inteiras a recortadas; frequentemente 1 ou vários pares de nectários extraflorais, peciolares ou basilaminares, opostos ou alternos; estípulas rudimentares, desenvolvidas ou ausentes. Inflorescências unifloras e solitárias ou plurifloras, em capítulos, cincinos laterais ou racemos terminais; brácteas ausentes ou presentes. Flores bissexuadas, actinomorfas, hipóginas, geralmente heterostilas; pedúnculo livre ou adnato ao pecíolo da folha (flor epífila); bractéolas (prófilos) 2, alternas ou opostas, às vezes rudimentares; pedicelo ausente ou desenvolvido. Cálice gamossépalo, 10-nervado, campanulado ou tubuloso, porção distal 5-laciniada, prefloração quincuncial. Pétalas 5, dialipétalas, alternissépalas, obovadas, unguiculadas, prefloração contorta, unha adnata ao tubo calicino, constituindo um tubo floral. Corona ausente ou presente. Estames 5, alternipétalos, filetes cilíndricos ou achatados dorsiventralmente, 
livres entre si ou porção dorso basal discretamente adnata ao tubo floral, às vezes, adnatos pelas margens à unha das pétalas, formando sacos nectaríferos; anteras bitecas, ovadas ou sagitadas, achatadas dorsiventralmente, dorsifixas ou basifixas, deiscência longitudinal, introrsa. Ovário súpero, ovoide, 3-carpelar, gamocarpelar, unilocular, placentação parietal, óvulos anátropos; estiletes 3, cilíndricos, glabros ou pilosos, estigmas geralmente penicelados. Frutos cápsulas loculicidas, 3-valvares, ovoides a globosas, epicarpo piloso, valvas internamente glabras, lustrosas. Sementes geralmente reticuladas; arilo unilateral ou envolvente.

\section{Chave de identificação dos gêneros de Turneraceae ocorrentes no Ceará}

1. Flores com corona membranácea, fimbriada, localizada na unha das pétalas e sobre as sépalas; indumento com tricomas tectores simples, estrelado-porrectos e glandulares setiformes de base inchada; pedicelo desenvolvido, 3-10 mm compr. 1. Piriqueta

1'. Flores sem corona; indumento com tricomas tectores simples, às vezes estrelados, mas nunca estreladoporrectos, e glandulares microcapitados, capitado-estipitados e capitado-sésseis; pedicelo ausente.....

1. Piriqueta Aubl., Hist. Pl. Guiane 1: 298. 1775. Ervas a arbustos; indumento com tricomas tectores simples, estrelados e estrelado-porrectos $\mathrm{e}$, frequentemente, tricomas glandulares setiformes de base inchada. Estípulas rudimentares. Folhas papiráceas a subcoriáceas; nectários extraflorais geralmente ausentes. Inflorescências unifloras e solitárias ou plurifloras, em cincinos laterais ou racemos terminais; brácteas ausentes. Flores com pedúnculo livre do pecíolo; bractéolas rudimentares ou desenvolvidas, neste caso, alternas, localizadas próximo da articulação do pedúnculo com o pedicelo; pedicelo desenvolvido, 3-10 mm compr., geralmente mais largo e escuro que o pedúnculo. Cálice com lacínios triangulares a estreito-triangulares, ápice agudo a mucronado. Corola creme, amarela, salmão ou rosa. Corona membranácea, fimbriada, localizada na unha das pétalas e sobre as sépalas. Filetes com porção dorso basal discretamente adnata ao tubo floral. Cápsulas com epicarpo piloso. Sementes retas ou curvas; calaza arredondada, obtusa a ligeiramente proeminente.

Piriqueta abrange 46 espécies unicamente americanas, as quais se distribuem desde o sul dos Estados Unidos ao norte da Argentina e Uruguai (Arbo 1995). No Brasil ocorrem 39 espécies (BFG 2015; Cabrera et al. 2015), cujo centro de diversidade se localiza no domínio da Caatinga, na Chapada Diamantina, estado da Bahia (Arbo \& Mazza 2011; Rocha \& Rapini 2016). Para o estado do Ceará foram registradas sete espécies, principalmente na vegetação da caatinga e cerrado, em áreas abertas, por vezes alteradas.

\section{Chave de identificação das espécies de Piriqueta ocorrentes no Ceará}

1. Inflorescências unifloras ou em racemos; bractéolas ausentes ou rudimentares reduzidas a um tufo de tricomas.

2. Corola em tons de amarelo; frutos com epicarpo liso.

3. Inflorescências em racemos terminais, alongados; sementes lunadas

1.4. Piriqueta racemosa

3’. Inflorescências unifloras, solitárias; sementes obovoides.

4. Flores homostilas .......................................1.1.1. Piriqueta cistoides subsp. cistoides

4'. Flores heterostilas..................................... 1.1.2. Piriqueta cistoides subsp. caroliniana

2'. Corola em tons de rosa; frutos com epicarpo tuberculado ou granuloso.

5. Ervas; flores homostilas; corola $8-9 \mathrm{~mm}$ compr......... 1.7. Piriqueta viscosa subsp. viscosa

5'. Subarbustos; flores heterostilas; corola $15-25 \mathrm{~mm}$ compr.

1.3. Piriqueta guianensis subsp. elongata

1'. Inflorescências em cincinos, 1-6 floros; bractéolas 0,7-2 mm compr., lineares. 
6. Corola salmão 1.2. Piriqueta dentata

6'. Corola creme, amarela ou amarelo-alaranjada.

7. Folhas concolores, elípticas, base atenuada, margens discretamente serreadas

1.6. Piriqueta sulfurea

7'. Folhas discolores, ovadas a estreito-ovadas, base arredondada ou cordada, margens simples a duplamente crenadas ou serreado-crenadas 1.5. Piriqueta sidifolia var. multiflora

1.1.1. Piriqueta cistoides (L.) Griseb. subsp. cistoides, Fl. Brit. W.I. 3:298. $1860 . \quad$ Fig. 1

Ervas $0,5-1 \mathrm{~mm}$ alt.; caules subglabros, tomentoso-hirsutos a híspidos, tricomas tectores simples, estrelados e estrelado-porrectos, ferrugíneos ou amarelos, tricomas glandulares ausentes. Folhas com pecíolo 0,5-5(-11) mm compr.; lâmina 1-8($11,5) \times 2-3(-4) \mathrm{cm}$, cartácea, às vezes discolor, elíptica, linear a ovada, base cuneada ou atenuada, ápice agudo ou obtuso, margens subinteiras; face adaxial esparso-hirsuta, face abaxial tomentosohirsuta a velutina. Inflorescências unifloras, solitárias. Flores homostilas; pedúnculo (3-)625(-37) mm compr.; bractéolas rudimentares; pedicelo 2-6(-9) $\mathrm{mm}$ compr. Cálice 3-8(-10) $\mathrm{mm}$ compr., externamente tomentoso, ferrugíneo. Corola 3-12 mm compr., amarela ou creme, base às vezes amarelo-escura. Corona ca. $0,5 \mathrm{~mm}$ compr., amarelo-escura. Filetes 2,2-4 mm compr., glabros. Estiletes 0,9-1,7 mm compr., glabros ou esparso-pilosos. Cápsulas 3-9 mm diâm.; epicarpo liso, subglabro ou esparso-piloso, tricomas tectores simples. Sementes 1,5-2 × 0,8-1 mm, obovoides, retas a ligeiramente curvas; epiderme papilosa. Iconografia: Arbo (1995, Fig. 57a-f: 131).

Material examinado: Crato, X.1838, aprox. $7^{\circ} 14^{\prime}$ 'S, $39^{\circ} 24^{\prime}$ 'W, fl. e fr., G. Gardner 1668-em parte (CGE-foto, OXF-foto, W-foto).

Material adicional examinado: BRASIL. BAHIA: Itaetê, zona rural, margens do Rio Paraguaçu, $13^{\circ} 0^{\prime}$ 'S,

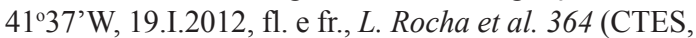
HUEFS, RB).

Ruderal, ocorre no México, Antilhas até a Argentina (Arbo 1995). É amplamente distribuída no Brasil, sendo registrada nas regiões Norte, Nordeste (apenas Bahia, Ceará, Maranhão), CentroOeste (exceto Brasília), Sudeste (exceto Espírito Santo) e Sul (apenas Paraná) (BFG 2015). No Ceará é conhecida através de uma única coleta, proveniente da região do Crato, obtida com flores e frutos em outubro. De modo geral, Piriqueta cistoides s.l. apresenta flores solitárias, com corola em tons de amarelo, fruto com epicarpo liso e sementes retas a ligeiramente curvas. Assemelha-se a Piriqueta racemosa, a qual pode ser diferenciada pelas flores dispostas em um racemo terminal alongado e sementes lunadas. Piriqueta cistoides subsp. cistoides pode ser reconhecida principalmente pelas flores homostilas e corola pequena (3-12 mm compr.). Medidas baseadas em Arbo (1995).

1.1.2. Piriqueta cistoides subsp. caroliniana (Walter) Arbo, Ann. Missouri Bot. Gard. 77(2): 351. 1990.

Fig. 1

Ervas 50-60 cm alt.; caules subglabros, tomentoso-hirsutos a híspidos, tricomas tectores simples, estrelados e estrelado-porrectos, ferrugíneos ou avermelhados, tricomas glandulares ausentes. Folhas subsésseis ou com pecíolo até 2(-8) mm compr.; lâmina $0,8-7(-10,5) \times 0,1-2,2$ $\mathrm{cm}$, menor no ápice dos ramos, cartácea, às vezes discolor, linear, elíptica, estreito-ovada a obovada, base cuneada, ápice obtuso ou agudo, margens inteiras ou serrilhadas; face adaxial esparso-pilosa a hirsuta, face abaxial glabra a hirsuta. Inflorescências unifloras, solitárias. Flores heterostilas; pedúnculo 4-16 mm compr.; bractéolas rudimentares ou até $0,6 \mathrm{~mm}$ compr.; pedicelo $2,5-8 \mathrm{~mm}$ compr. Cálice 4,7-11 mm compr., externamente glabro ou hirsuto, dourado a ferrugíneo. Corola 6,7-21 $\mathrm{mm}$ compr., amarela, base amarelo-escura. Corona ca. 0,5 mm compr., amarelo-escura. Filetes 5-9 $\mathrm{mm}$ compr. em flores brevistilas, $3-5 \mathrm{~mm}$ compr. em flores longistilas, glabros. Estiletes 1,3-3 mm compr. em flores brevistilas, 3,5-6 mm compr. em flores longistilas, glabros. Cápsulas $4-5 \mathrm{~mm}$ diâm.; epicarpo liso, subglabro ou esparso-piloso, tricomas tectores simples. Sementes 1,5-2,1 $\times$ 0,9-1,2 $\mathrm{mm}$, obovoides, retas a ligeiramente curvas; epiderme papilosa.

Iconografia: Arbo (1995, Fig. 58a-r: 138).

Material examinado: Crato, X.1838, aprox. $7^{\circ} 14^{\prime}$ 'S, $39^{\circ} 24^{\prime}$ W, fl. e fr., G. Gardner 1668-em parte (K-foto, W-foto).

Material adicional examinado: BRASIL. BAHIA: Xique-Xique, 10-12 km S, na estrada para Barra, carnaubal ao lado do Rio São Francisco, 10 $0^{\circ} 50^{\prime}$ 'S, $42^{\circ} 42^{\prime}$ 'W, 15.XI.1984, fl. e fr., L.R. Noblick 3464 (CTES, HUEFS). 
Ruderal, ocorre no sudeste dos Estados Unidos, Antilhas, Colômbia, Venezuela, Bolívia e Brasil, neste último é registrada nas Regiões Norte (Acre, Pará, Roraima e Tocantins), Nordeste (exceto Ceará, Paraíba e Pernambuco), Centro-Oeste (exceto Brasília) e Sudeste (Minas Gerais e São Paulo) (Arbo 1995; BFG 2015). No Ceará também é conhecida através de uma única coleta, proveniente da região do Crato, obtida com flores e frutos em outubro. A coleta G. Gardner 1668 inclui três táxons distintos: as duas subespécies de Piriqueta cistoides e Piriqueta racemosa; considerando que as duplicatas foram incorporadas a herbários diferentes, os vouchers estão citados como partes. Piriqueta cistoides subsp. caroliniana pode ser reconhecia pelas flores heterostilas e corola geralmente maior que na subespécie típica $(6,7-21 \mathrm{~mm}$ compr.). Medidas baseadas em Arbo (1995).

\subsection{Piriqueta dentata Arbo, Fl. Neotrop. Monogr.} 67: 40. 1995.

Figs. 1; 2a; 9a

Arbustos $50-70 \mathrm{~cm}$ alt.; caules tomentosos, tricomas tectores simples e estrelado-porrectos, ferrugíneos ou amarelos, e glandulares setiformes.
Folhas com pecíolo 2,5-5 mm compr.; lâmina $2,2-3,8 \times 1,5-2,4 \mathrm{~cm}$, cartácea a quase coriácea, discolor, ovada, oval-elíptica a largo-ovada, base cuneada ou atenuada, ápice agudo, margens denteadas; as duas faces tomentoso-hirsutas a velutinas. Inflorescências plurifloras, em cincinos 1-3-floros. Flores heterostilas; pedúnculo 1-1,6 mm compr.; bractéolas 1-2 mm compr., lineares. pedicelo 3-5 mm compr. Cálice 9-12 mm compr., externamente tomentoso, ferrugíneo. Corola 11-16 mm compr., salmão, base das pétalas roxa. Corona ca. 0,5 mm compr., roxa. Filetes 5-6 mm compr. em flores brevistilas, ca. $4 \mathrm{~mm}$ compr. em flores longistilas, glabros ou esparso-pilosos. Estiletes 2-2,5 mm compr. em flores brevistilas, ca. $7 \mathrm{~mm}$ compr. em flores longistilas, glabros ou esparso-pilosos. Cápsulas 5-6 mm diâm.; epicarpo tuberculado, tomentoso-hirsuto, tricomas tectores estrelado-porrectos. Sementes 2,3-2,5 × 0,9-1 mm, obovoides, ligeiramente curvas; epiderme papilosa. Iconografia: Arbo (1995, Fig. 22e-j: 39).

Material examinado: São Benedito, Chapada da Ibiapaba, 402'55"'S, 40 51'54”'W, 7.XII.1990, fl. e fr., A. Fernandes (EAC 17075). Sobral, Taperuaba, 341'10"'S, 40²0'59”'W, 9.VI.1991, fl. e fr., A. Fernandes (EAC 17436).
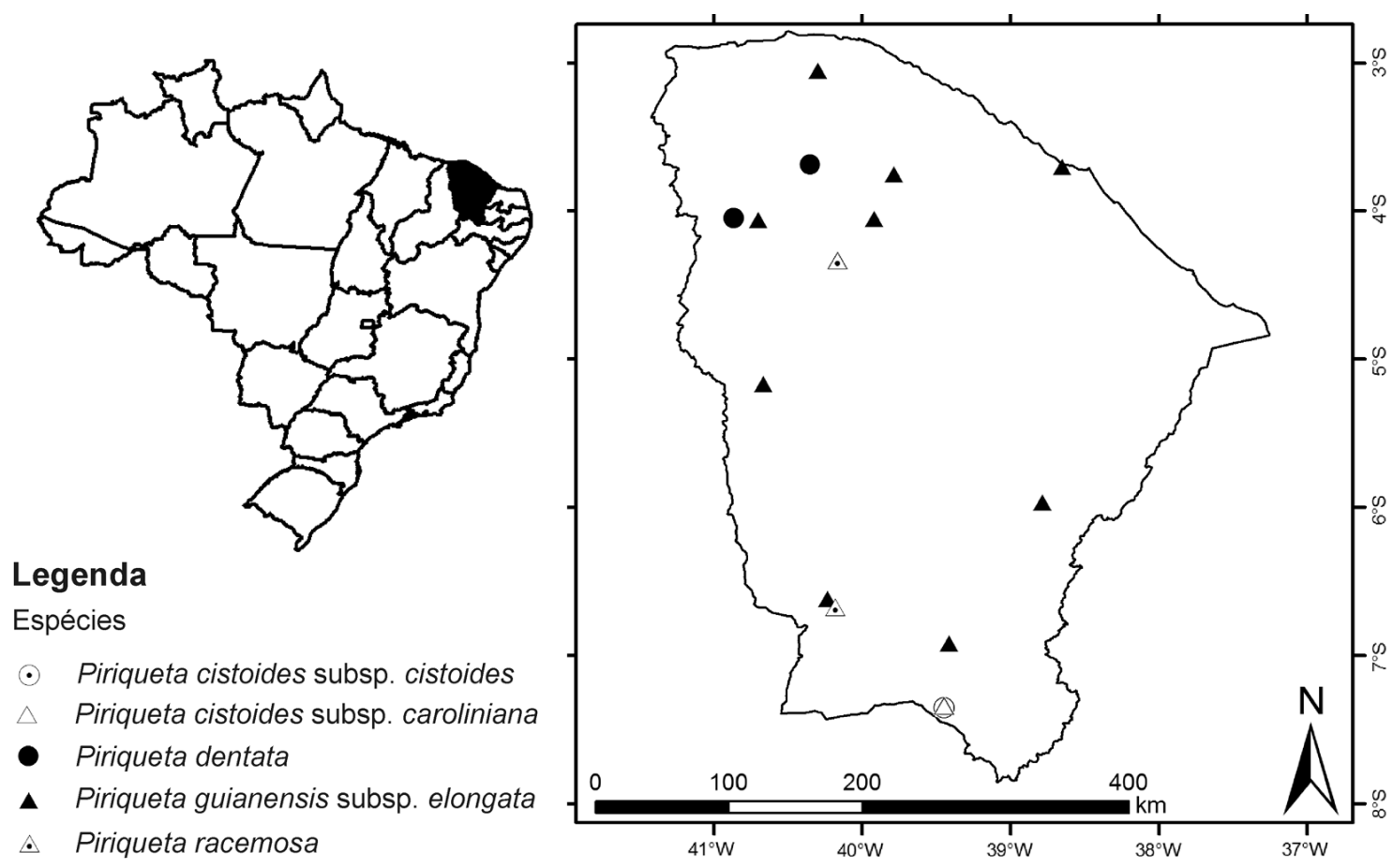

Figura 1 - Distribuição de Piriqueta cistoides subsp. cistoides, P. cistoides subsp. caroliniana, P. dentata, P. guianensis subsp. elongata e P. racemosa no estado do Ceará.

Figure 1 - Distribution of Piriqueta cistoides subsp. cistoides, P. cistoides subsp. caroliniana, P. dentata, P. guianensis subsp. elongata e P. racemosa in Ceará state. 

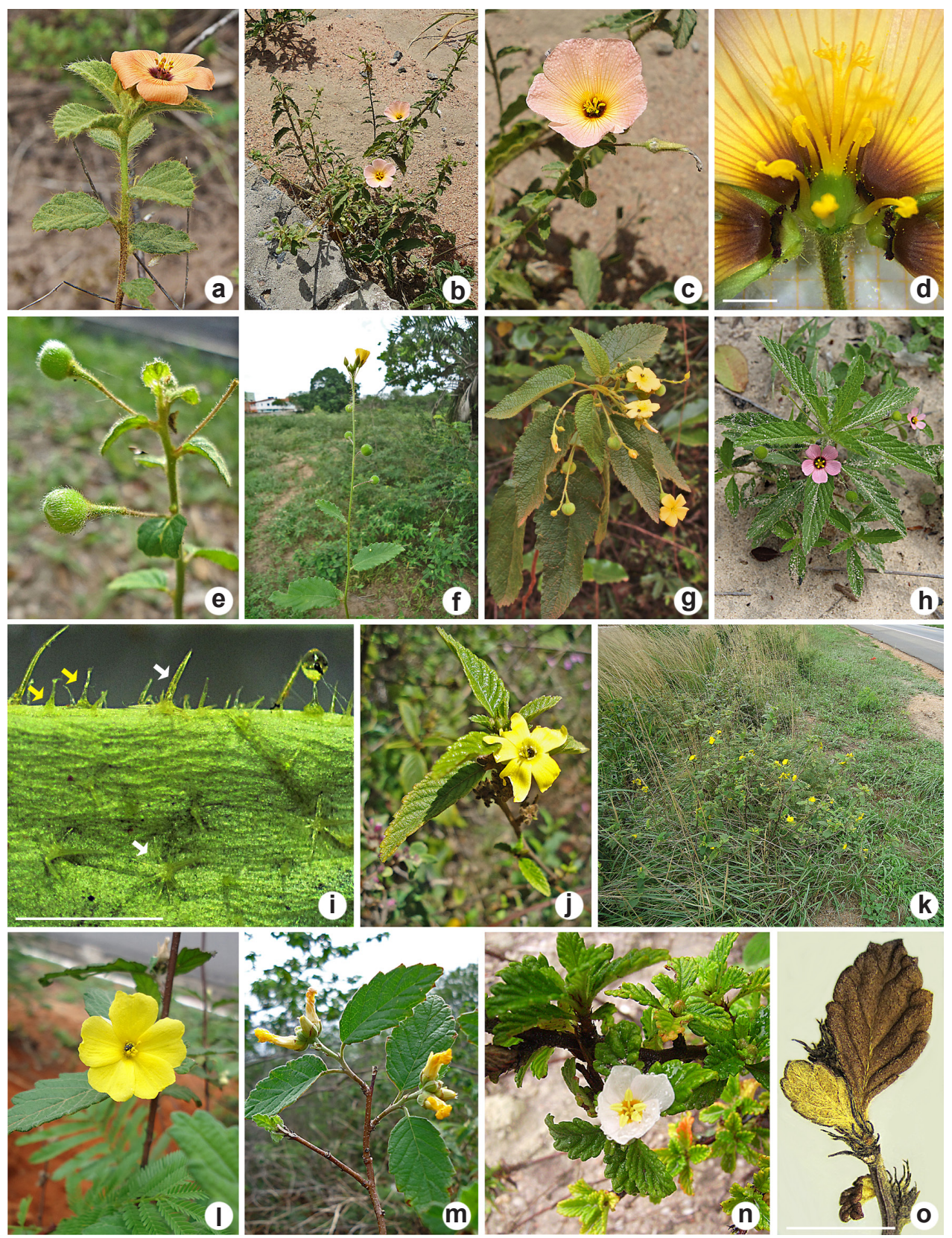

Figura 2 - a. Piriqueta dentata - ramo com flor; b-e. P. guianensis subsp. elongata - b. hábito; c. ramo com flor; d. flor longistila evidenciando a porção interna tubo do floral, com cinco estames, pistilo e corona na base das pétalas (escala $=1 \mathrm{~mm}$ ); e. ramo com frutos; f. P. racemosa - ramo com flores e frutos; g. P. sidifolia var. multiflora - ramo com flores e frutos; h,i. P. viscosa subsp. viscosa $-\mathrm{h}$. ramo com flor; i. indumento da folha (face adaxial): tricomas tectores estrelado-porrectos (setas brancas) e tricomas glandulares setiformes (setas amarelas) $(\mathrm{escala}=1 \mathrm{~mm}) ; \mathrm{j}$. Turnera bahiensis var. truncata - ramo com flor; $\mathrm{k}-\mathrm{m} . T$. blanchetiana var. blanchetiana - $\mathrm{k}$. hábito; 1 . ramo com flor; $\mathrm{m}$. ramo evidenciando inflorescências; n,o. T. calyptrocarpa $-\mathrm{n}$. ramo com flor; o. ramo evidenciando folhas e estípulas (escala $=5 \mathrm{~mm}$ ). (a-f, h-m, o: L. Rocha; g: A. Rapini; $\mathrm{n}$ : A. Alves).

Figure 2 - a. Piriqueta dentata - branch with flower; b-e. P. guianensis subsp. elongata - b. habit; c. branch with flower; d. long-styled flower showing the inner face of the floral tube, with five stamens, pistil and corona at the base of petals (scale $=1 \mathrm{~mm}$ ); e. branch with fruits; f. $P$. racemosa - branch with flowers and fruits; g. P. sidifolia var. multiflora - branch with flowers and fruits; h,i. $P$. viscosa subsp. viscosa - h. branch with flower; i. indumentum of leaves (upper surface): porrect-stellate tector trichomes (white arrows) and setiform glandular trichomes (yellow arrows) $($ scale $=1 \mathrm{~mm}) ; \mathrm{j}$. Turnera bahiensis var. truncata - branch with flower; $\mathrm{k}-\mathrm{m}$. T. blanchetiana var. blanchetiana $-\mathrm{k}$. habit; 1 . branch with flower; $\mathrm{m}$. branch showing inflorescences; $\mathrm{n}$,o. T. calyptrocarpa $-\mathrm{n}$. branch with flower; $\mathrm{o}$. branch showing leaves and stipules (scale $=5 \mathrm{~mm}$ ). (a-f, h-m, o: L. Rocha; g: A. Rapini; n: A. Alves). 
Material adicional examinado: BRASIL. BAHIA: Morro do Chapéu, estrada para o Morrão, 11³5'4"S, $41^{\circ} 12^{\prime} 10^{\prime \prime} \mathrm{W}, 1.157$ m, 12.I.2005, fl. e fr., S.F. Conceição et al. 107 (HUEFS).

Rara, ocorre principalmente na Chapada Diamantina, na Bahia (Arbo 1995, 2017). No Ceará foi encontrada apenas em duas localidades, associada a ambientes secos como vegetação de carrasco e em áreas abertas de caatinga. Floresce e frutifica em junho e dezembro. Pode ser reconhecida pelo indumento ferrugíneo ou amarelo, folhas com margens denteadas e corola salmão. Assemelha-se a Piriqueta duarteana (Cambess.) Urb., ainda não registrada no Ceará, a qual pode ser diferenciada pelas inflorescências unifloras solitárias ( $v s$. cincinos 1-3-floros) e epicarpo com tricomas setiformes de base castanho-escura ( $v s$. epicarpo com apenas tricomas tectores estreladoporrectos). Os espécimes do Ceará apresentam caules tomentosos, com tricomas estreladoporrectos com raio central robusto e curto, geralmente menor que $1 \mathrm{~mm}$ compr., diferente dos espécimes do estado da Bahia, com caules tomentoso-hirsutos e tricomas estrelado-porrectos com raio central longo, 2-4 mm compr. (Rocha \& Rapini 2016). Consideramos, contudo, que essas diferenças podem se tratar de uma variação morfológica da espécie.

1.3. Piriqueta guianensis subsp. elongata (Urb. \& Rolfe) Arbo, Fl. Neotrop. Monogr. 67: 116. 1995.

Figs. 1; 2b-e; $9 \mathrm{~b}$

Subarbustos 0,4-1 m alt.; caules esparsopilosos a tomentosos, tricomas tectores simples, estrelados e estrelado-porrectos, marrom-dourados, e glandulares setiformes. Folhas com pecíolo até $6 \mathrm{~mm}$ compr.; lâmina 1,2-5,4 ×0,7-2,4 cm, às vezes menores no ápice dos ramos, cartácea, discolor, ovada, largo-ovada, elíptica a lanceolada, base cuneada, ápice agudo ou obtuso, margens discretamente serreadas a quase inteiras; as duas faces tomentoso-velutinas. Inflorescências unifloras, solitárias ou agrupadas no ápice dos ramos. Flores heterostilas; pedúnculo $(0,5-) 1,1-1,8$ mm compr.; bractéolas rudimentares, reduzidas a um tufo de tricomas; pedicelo 3-6 mm compr. Cálice 8-12 mm compr., externamente tomentoso. Corola 15-25 mm compr., salmão a rosa, base das pétalas amarela e vinácea. Corona 0,7-1 mm compr., vinácea. Filetes ca. $7 \mathrm{~mm}$ compr. em flores brevistilas, ca. 4,5 $\mathrm{mm}$ compr. em flores longistilas, glabros. Estiletes ca. $2 \mathrm{~mm}$ compr. em flores brevistilas, 4-4,5 mm compr. em flores longistilas, glabros ou esparso-pilosos. Cápsulas 5-6 mm diâm.; epicarpo granuloso, esparsohirsuto, tricomas tectores simples e glandulares setiformes de base hialina. Sementes 2-2,2 $\times$ ca. $0,7 \mathrm{~mm}$, estreito-obovoides, retas a ligeiramente curvas; epiderme papilosa.

Iconografia: Arbo (1995, Fig. 52f-i: 114).

Material selecionado: Aiuaba, Estação Ecológica de Aiuaba, 63'ㅇ, 40¹4'W, 480 m, 30.V.1996, fl. e fr., M.I.B. Loiola et al. 182 (EAC). Caucaia, Parque Botânico do Ceará, 342'S, 38³9'W, 25.III.1998, fl. e fr., E. Nunes \& F.S. Cavalcanti (EAC 26230). Crateús, Serra das Almas, 510'S, 4040’W, 27.II.2002, fl. e fr., F.S. Araújo \& S.F. Vasconcelos 1349 (EAC, HUEFS). Irauçuba, Fazenda Aroeira, 34' 'S, 3947'W, 22.IV.2005, fl. e fr., E.R.C. Trigueiro (EAC 35569). Jaguaribe, Sítio Maniçoba, 66'S, 38³4'W, 12.IX.1984, fl. e fr., G.C.P. Pinto et al. 257-84 (CTES, HRB, RB). Pacujá, distrito Bom Gosto, Serrinha, início da trilha para o platô da Serrinha, 4'3'33"S, 4042'13”'W, 270 m, 28.III.2012, fl. e fr., E.B. Souza et al. 2410 (HUEFS, HUVA). Santa Quitéria, Fazenda Intan de Cima, Serra do Pajé, 4²0'S, $40^{\circ} 10^{\prime}$ W, 8.V.1997, fl. e fr., L.W. Lima-Verde (EAC 25566). São Gonçalo do Amarante, $3^{\circ} 3^{\prime} \mathrm{S}, 40^{\circ} 18^{\prime} \mathrm{W}$, 21.III.2006, fl. e fr., A.S.F. Castro 1710 (EAC). Sobral, Fazenda de Macapá, Taperuaba, 43'S, 3955'W, 1.V.2001, fl. e fr., A. Fernandes (EAC 30720). Várzea Alegre, BR-230, km 25, entre o município de Farias Brito, 6 ${ }^{\circ} 55^{\prime} \mathrm{S}, 3^{\circ} 25^{\prime} \mathrm{W}, 290 \mathrm{~m}, 7 . \mathrm{VI} .1985$, fl. e fr., A. Fernandes et al. (EAC 13255); Naraniu, CE-021, 5'21'S, 40²3'W, 18.V.1985, fl. e fr., A. Fernandes et al. (EAC 13205).

Ruderal, ocorre na Guiana e Norte (Roraima) e Nordeste do Brasil (exceto Maranhão) (Arbo 1995; BFG 2015). No Ceará foi encontrada na vegetação de caatinga arbustivo-arbórea, matas secas, tabuleiros litorâneos e campos, em áreas abertas e margens de trilhas; cresce em substratos arenosos ou areno-argilosos. Floresce e frutifica durante o ano todo. Pode ser reconhecida pelas flores solitárias com corola salmão ou rosa e base das pétalas amarela ou vinácea, além do epicarpo com tricomas glandulares setiformes de base hialina. Assemelha-se a Piriqueta duarteana, não registrada no Ceará, a qual se diferencia principalmente pelos pedúnculos florais geralmente mais curtos e epicarpo com tricomas glandulares setiformes com base castanho-escura. Arbo (1995) considerou duas subespécies para Piriqueta guianensis: $P$. guianensis subsp. guianensis e $P$. guianensis subsp. elongata (Urb. \& Rolfe) Arbo, apenas esta última ocorre no Ceará. A subespécie típica se caracteriza pelos estiletes pilosos e sementes geralmente pequenas, 1,5-1,8 $\mathrm{mm}$ compr.; enquanto $P$. guianensis subsp. elongata 
apresenta estiletes glabros a esparso-pilosos e sementes maiores, 1,9-2,3 mm compr.

1.4. Piriqueta racemosa (Jacq.) Sweet, Hort. Brit. 1: 154.1826.

Figs. 1; 2f; 9c

Ervas a subarbustos $0,2-1,3 \mathrm{~m}$ alt.; caules hirsutos a tomentoso-hirsutos, tricomas tectores simples, estrelados e estrelado-porrectos, ferrugíneos, tricomas glandulares ausentes. Folhas com pecíolo 5-13 mm compr.; lâmina 2,3-8 × $1,2-4 \mathrm{~cm}$, menor no ápice dos ramos, papirácea, concolor ou discolor, ovada, largo-ovada, elíptica a lanceolada, base cuneada, arredondada ou atenuada, ápice agudo, margens simples a duplamente serreado-crenadas; face adaxial denso pilosa a velutina, face adaxial tomentosovelutina. Inflorescências em racemos terminais alongados, até $30 \mathrm{~cm}$ compr. Flores heterostilas ou homostilas; pedúnculo 1-3 cm compr.; bractéolas ausentes; pedicelo 4-6 mm compr. Cálice 4-6 $\mathrm{mm}$ compr., externamente tomentoso-hirsuto, dourado a ferrugíneo. Corola 9-11 mm compr., creme ou amarela. Corona $0,5-0,7 \mathrm{~mm}$ compr., castanho-escura. Filetes 2,5-3 mm compr., glabros. Estiletes 3-3,5 mm compr., glabros. Cápsulas 6-10 mm diâm.; epicarpo liso, esparso-setoso, tricomas tectores estrelado-porrectos. Sementes 1,5-2 $\times$ 0,5-0,7 $\mathrm{mm}$, lunadas, epiderme papilosa.

Iconografia: Arbo (1995, Fig. 59a-f: 142).

Material selecionado: Aiuaba, Estação Ecológica de Aiuaba, 6040'25”'S, 40¹0'54”'W, 410 m, 9.I.1997, fl. e fr., M.A. Figueiredo et al. 653 (EAC). Quixeré, Chapada do Apodi, Fazenda Mato Alto-Manga do Mamoeiro, 6012'13,2"S, 37049'10,1"W, 110 m, 14.V.1997, fl. e fr., L.M.R. Melo \& O.M. Gomes 96 (EAC). Santa Quitéria, Fazenda Itatiaia, $4^{\circ} 20^{\prime} \mathrm{S}, 40^{\circ} 10^{\prime} \mathrm{W}, 27 . \mathrm{IV} .1984$, fl. e fr., A. Fernandes et al. (EAC 12534).

Material adicional examinado: BRASIL. BAHIA: Nova Itarana, a $1 \mathrm{~km}$ da BR-116, entrada de Nova Itarana, $13^{\circ} 2^{\prime}$ 'S, $40^{\circ} 6^{\prime} \mathrm{W}$, 4.IV.2013, fl. e fr., L. Rocha et al. 390 (ALCB, CTES, HUEFS). Feira de Santana, Estrada do Feijão, lado esquerdo, $12^{\circ} 26^{\prime} \mathrm{S}, 38^{\circ} 96^{\prime} \mathrm{W}, 30 . \mathrm{IV} .2012$, fl., L. Rocha \& I. Souza 375 (CTES, HUEFS). RIO GRANDE DO NORTE: Jucurutu, RPPN Stoessel de Brito, 6 $2^{\circ}$ 'S, $37^{\circ} 1^{\prime} \mathrm{W}, 1 . \mathrm{VI} .2008$, fl. e fr., A.A. Roque 575 (HUEFS, UFRN).

Ocorre nas Antilhas, Colômbia, Venezuela e Paraguai, além do Velho Mundo (Arbo 1995). No Brasil, é registrada no Nordeste (exceto Maranhão) e Sudeste (Espírito Santo, Minas Gerais e Rio de Janeiro) (Arbo 1995, BFG 2015). No Ceará foi encontrada na caatinga arbórea, em áreas abertas, por vezes, antropizadas, como margens de rodovias ou trilhas; cresce sobre substratos quartzíticos.
Floresce e frutifica durante o ano todo. Pode ser reconhecida pelos caules tomentoso-hirsutos, flores reunidas em um racemo terminal alongado, epicarpo liso e sementes lunadas. Assemelha-se a Piriqueta cistoides (L.) Griseb., a qual se diferencia pelas flores solitárias e sementes obovoides.

1.5. Piriqueta sidifolia var. multiflora Urb., Jahrb. Königl. Bot. Gart. Berlin 2: 61. 1883.

Figs. $2 \mathrm{~g} ; 3 ; 9 \mathrm{~d}$

Ervas a arbustos $0,5-1,5 \mathrm{~m}$ alt.; caules pilosos a esparso-pilosos, tricomas tectores simples e estrelado-porrectos, dourados, e glandulares setiformes. Folhas com pecíolo 0,7-2,2 cm compr.; lâmina 2,7-9 × 8-4,5 cm, cartácea, discolor, ovada a estreito-ovada, base arredondada ou cordada, ápice agudo ou obtuso, margens simples a duplamente crenadas ou serreado-crenadas; face adaxial esparso a denso-pilosa, às vezes velutina, face abaxial tomentosa a tomentosovelutina. Inflorescências plurifloras, em cincinos 2-6-floros. Flores heterostilas; pedúnculo 2,5-4 cm compr.; bractéolas 1-2 mm compr., lineares; pedicelo 3-10 mm compr. Cálice 7-10 mm compr., externamente tomentoso, dourado-ferrugíneo. Corola $13-15 \mathrm{~mm}$ compr., amarela ou creme, base das pétalas amarelo-escura. Corona 0,8-1 mm compr., castanho-escura. Filetes ca. $5 \mathrm{~mm}$ compr. em flores brevistilas, 3-3,5 $\mathrm{mm}$ compr. em flores longistilas, glabros. Estiletes ca. 1,5 mm compr. em flores brevistilas, 4-4,5 $\mathrm{mm}$ compr. em flores longistilas, glabros. Cápsulas 6-7 mm diâm.; epicarpo granuloso a tuberculado, hirsuto, tricomas tectores simples e estrelado-porrectos. Sementes 2-2,7 ×0,7-1 mm, estreito-obovoides, ligeiramente curvas; epiderme papilosa.

Iconografia: Arbo (1995, Fig. 28a-g: 54).

Material selecionado: Aiuaba, distrito de Barra, Estação Ecológica de Aiuaba, Serra Nova, 6 $6^{\circ} 38^{\prime} \mathrm{S}, 40^{\circ} 7^{\prime} \mathrm{W}$, 640 m, 14.I.1998, fl. e fr., M.A. Figueiredo et al. 945 (EAC). Barbalha, Caldas, Subida da Serra, 7'22'29"'S, 39²0'18”'W, 922 m, 23.V.2011, fl. e fr., E. Melo et al. 9742 (HUEFS). Crato, estrada velha da Minguiriba, 7¹7’34”S, 39³2'30”'W, 919 m, 22.X.2011, fl. e fr., E.B. Souza et al. 2117 (HUEFS). Guaraciaba do Norte, Chapada da Ibiapaba, 410'S, 4046’W, 30.IV.1994, fl. e fr., A. Fernandes \& Matos (EAC 21230). Jati, estrada para São José do Belmonte/PB, $7^{\circ} 43^{\prime}$ 'S, 38 $38^{\circ} 58^{\prime} \mathrm{W}, 511 \mathrm{~m}$, 18.I.2009, fl. e fr., J.G. Carvalho-Sobrinho et al. 1965 (CTES, HVASF). Missão Velha, Cachoeira da Missão Velha, Chapada do Araripe, $7^{\circ} 13^{\prime} 17^{\prime \prime} \mathrm{S}, 39^{\circ} 8^{\prime} 37^{\prime} \mathrm{W}, 341$ m, 11.VII.2012, fl. e fr., R.A. Silva et al. 2034 (HVASF). Novo Oriente, planalto do Ibiapaba, $5^{\circ} 3^{\prime} \mathrm{S}, 40^{\circ} 55^{\prime} \mathrm{W}$, 18.II.1991, fl. e fr., F.S. Araújo 263 (EAC). Santana do Cariri, Guritiba, Chapada do Araripe, $7^{\circ} 11^{\prime}$ 'S, 39 $44^{\prime} \mathrm{W}$, 
27.VII.2004, fl. e fr., A.S.F. Castro 1524 (EAC). Tianguá, Chapada da Ibiapaba, 343'S, 4059'W, 29.IV.1987, fl. e fr., A. Fernandes \& Matos (EAC 15061). Ubajara, Jaburuna-sul, planalto da Ibiapaba, $3^{\circ} 51^{\prime} \mathrm{S}, 40^{\circ} 55^{\prime} \mathrm{W}$, 830 m, 5.I.1995, fl. e fr., F.S. Araújo 1044 (CTES, EAC).

Ocorre apenas no Brasil, onde é amplamente distribuída no Centro-Oeste (Distrito Federal, Goiás e Mato Grosso do Sul), Nordeste (Bahia, Ceará, Maranhão, Pernambuco e Piauí), Norte (Tocantins), Sudeste (Minas Gerais) e Sul (Rio Grande do Sul) (Arbo 1995; BFG 2015). No Ceará, foi encontrada principalmente no cerrado e carrasco, além da caatinga arbórea e floresta úmida, em áreas alteradas, abertas ou na borda da mata; cresce sobre substratos arenosos. Floresce e frutifica durante o ano todo. Pode ser reconhecida pelas folhas ovadas a estreito-ovadas com base arredondada ou cordada e flores com corola amarela ou creme, com base das pétalas amarelo-escura. Assemelha-se a Piriqueta densiflora Urb., não registrada no Ceará, e se diferencia, principalmente, pelas folhas estreito-oblongas, estreito-elípticas a lineares, com indumento do caule ferrugíneo. Arbo (1995) considerou duas variedades para Piriqueta sidifolia: $P$. sidifolia var. sidifolia e $P$. sidifolia var. multiflora Urb., apenas esta última ocorre no
Ceará. A variedade típica apresenta hábito herbáceo a subarbustivo, folhas com pecíolos curtos (0,5-7 mm compr.) e inflorescências com 2-3(-6) flores; já Piriqueta sidifolia var. multiflora exibe hábito arbustivo, pecíolos maiores (2-3 cm compr.) e inflorescências com mais de quatro flores.

1.6. Piriqueta sulfurea Urb. \& Rolfe, Jahrb. Königl. Bot. Gart. Berlin 2: 62. 1883 . Fig. 3

Subarbustos 30-90 cm alt.; caules tomentosos a tomentoso-hirsutos, tricomas tectores simples, estrelados e estrelado-porrectos, dourados a marrom-dourados, e glandulares setiformes. Folhas com pecíolo 10-18 mm compr.; lâmina 3,5-7,3 $\times$ 1,5-3 cm, cartácea, concolor, elíptica, base atenuada, ápice obtuso, margens discretamente serreadas; as duas faces tomentoso-velutinas. Inflorescências plurifloras, em cincinos 2 ou 3-floros. Flores heterostilas; pedúnculo ca. 1,1 cm compr.; bractéolas ca. 0,7 mm compr., lineares; pedicelo ca. $8 \mathrm{~mm}$ compr.. Cálice $8-10 \mathrm{~mm}$ compr., externamente tomentoso-hirsuto, dourado. Corola ca. $13 \mathrm{~mm}$ compr., creme ou amarelo-alaranjada. Corona ca. 0,7 mm compr., castanho-escura. Filetes ca. $4 \mathrm{~mm}$ compr. em flores brevistilas, ca. $3 \mathrm{~mm}$

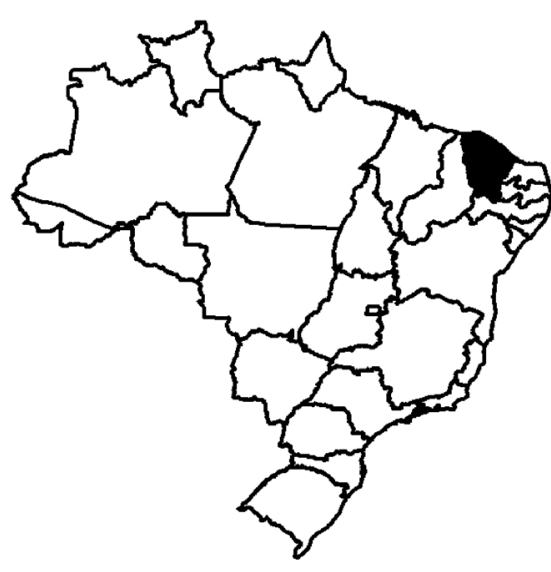

Legenda

Espécies

- Piriqueta sidifolia var. multiflora

- Piriqueta sulfurea

- Piriqueta viscosa subsp. viscosa

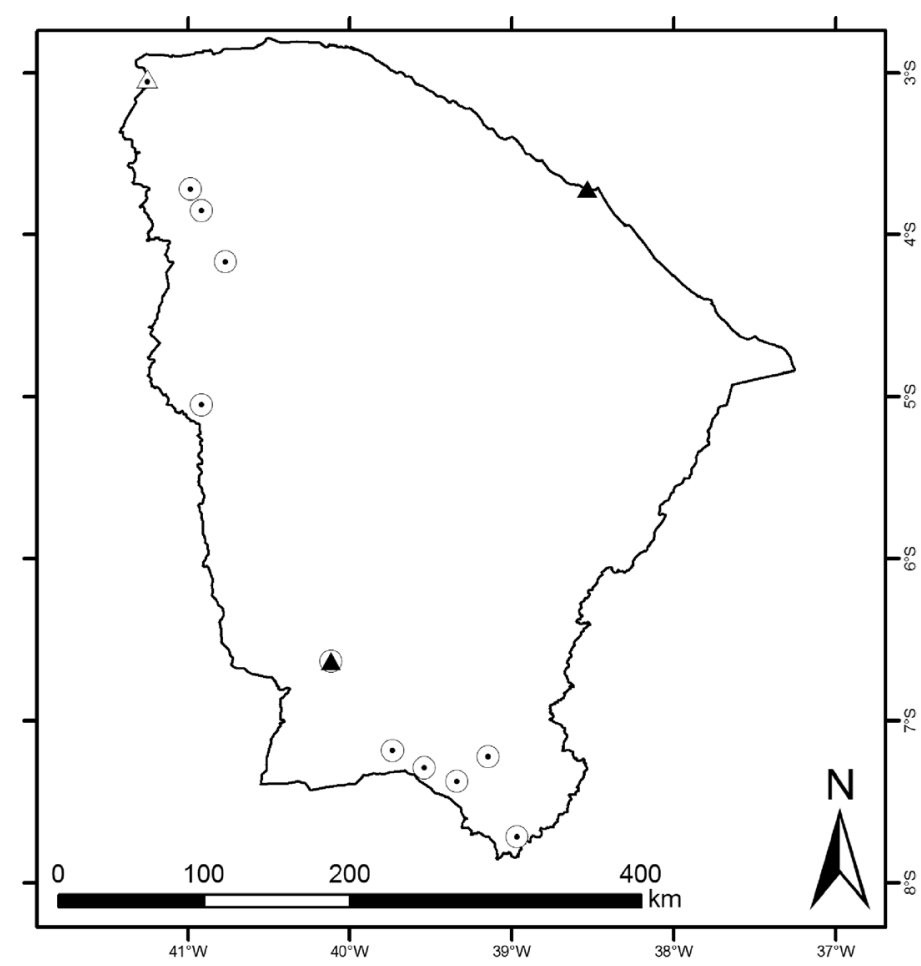

Figura 3 - Distribuição de Piriqueta sidifolia var. multiflora, $P$. sulfurea e $P$. viscosa subsp. viscosa no estado do Ceará. Figure 3 - Distribution of Piriqueta sidifolia var. multiflora, $P$. sulfurea and $P$. viscosa subsp. viscosa in Ceará state. 
compr. em flores longistilas, glabros. Estiletes ca. $2 \mathrm{~mm}$ compr. em flores brevistilas, ca. 4,5 mm compr. em flores longistilas, glabros. Cápsulas 5-7 mm diâm.; epicarpo granuloso, hirsuto, tricomas tectores estrelado-porrectos. Sementes 2-2,7 $\times 1-1,3 \mathrm{~mm}$, obovoides, ligeiramente curvas; epiderme papilosa.

Iconografia: Arbo (1995, Fig. 26e-j: 47).

Material examinado: Chaval, Ilha do Saboia, 3'2'S, $41^{\circ} 15^{\prime}$ W, 5.V.2004, fl. e fr., A. Fernandes (EAC 33849). Material adicional examinado: BRASIL. PIAUÍ: Oeiras, Alto do Morro do Cruzeiro, 7¹'3''S, 42 8'35'W, 221 m, 23.I.2012, fl., R.M. Harley et al. 56385 (HUEFS).

Ocorre apenas no Brasil, nos estados da Bahia, Ceará e Piauí (BFG 2015; Rocha \& Rapini 2016). No Ceará está sendo registrada por apenas um espécime, encontrado nos tabuleiros litorâneos, crescendo em áreas abertas, sobre substrato arenoso. Floresce e frutifica em janeiro e maio. Pode ser reconhecida pelas folhas elípticas, concolores e flores com corola creme ou amarelo-alaranjada; os espécimes geralmente adquirem uma coloração dourado-pálida, quando secos, facilitando sua identificação. Assemelha-se a Piriqueta duarteana, que se diferencia pelos pecíolos geralmente mais curtos (2-16 mm compr.), inflorescências unifloras e corola salmão ou rosa (Arbo 1995).

1.7. Piriqueta viscosa Griseb. subsp. viscosa, Cat. Pl. Cub. 114. 1866.

Figs. 2h,i; 3

Ervas 25-40 cm alt., caules hirsutos, viscosos, tricomas tectores simples, estreladoporrectos, dourados, e abundantes glandulares setiformes. Folhas com pecíolo 2,5-10 mm compr.; lâmina 1,8-7,5 ×0,4-2,5 cm, papirácea, concolor ou discolor, elíptica a lanceolada, base atenuada, ápice agudo, margens serreadas; as duas faces esparso-pilosas, às vezes, face abaxial denso-pilosa. Inflorescências unifloras, solitárias. Flores homostilas; pedúnculo 1,5-2,5 cm compr.; bractéolas ausentes; pedicelo 4-6 mm compr. Cálice 5-6 mm compr., externamente esparsohirsuto principalmente na base, marrom-dourado. Corola 8-9 mm compr., rosa a rosa-escura, base das pétalas roxa. Corona ca. $0,5 \mathrm{~mm}$ compr., roxa. Filetes 3-4 mm compr., glabros. Estiletes 1,5-2,5 mm compr., glabros. Cápsulas 5-9 mm diâm.; epicarpo granuloso, esparso-hirsuto, tricomas tectores simples e glandulares setiformes. Sementes 2-2,2 × 0,9-1 mm, estreito-obovoides, retas a ligeiramente curvas; epiderme lisa.

Iconografia: Arbo (1995, Fig. 48a-c: 104).

Material examinado: Aiuaba, Estação Ecológica, 6038'S, 407'W, 30.IV.1981, fl. e fr., P. Martins \& Helda
(EAC 10250). Fortaleza, campo da Escola de Agronomia, 3०43'S, 38³2'W, 26.VI.1963, fl. e fr., A. Fernandes (CTES, EAC 2221).

Material adicional examinado: BRASIL. BAHIA: Caetité, $10 \mathrm{~km}$ antes de Caetité, estrada saindo de Brejinho das Ametistas, antes do posto de mineração, 27.IV.2013, fl. e fr., L. Rocha \& P. Gomes 425 (HUEFS). Mucugê, a $5 \mathrm{~km}$ da cidade, estrada para Andaraí, $13^{\circ} 0^{\prime}$ S, $41^{\circ} 37^{\prime} \mathrm{W}, 17 . \mathrm{I} .2012$, fl. e fr., L. Rocha et al. 355 (HUEFS). Palmeiras, estrada para o Capão, próximo ao povoado Rio Grande, 12³5'36”S, 41³0'23”W, 955 m, 29.IV.2012, fl. e fr., L. Rocha \& I. Souza 372 (HUEFS).

Ocorre na Mesoamérica, Antilhas, Colômbia e Venezuela (Arbo 1995). No Brasil, distribui-se no Centro-Oeste (Mato Grosso do Sul e Mato Grosso), Nordeste (Bahia, Ceará, Maranhão, Paraíba, Piauí e Rio Grande do Norte), Norte (Pará, Roraima) e Sudeste (Espírito Santo, Minas Gerais e Rio de Janeiro) (BFG 2015). No Ceará foi encontrada nos tabuleiros litorâneos e capoeiras, geralmente em áreas abertas ou antropizadas; cresce em substratos arenosos. Floresce e frutifica durante o ano todo. Pode ser reconhecida pelos caules viscosos, flores homostilas com corola rosa a rosa-escura, e base das pétalas roxa, além das sementes estreitoobovoides com epiderme lisa. Assemelha-se a Piriqueta morongii Rolfe, que ocorre apenas no Centro-Oeste, e se diferencia principalmente, pelas flores heterostilas, com corola maior (9-19 mm compr.) e sementes com epiderme papilosa. Arbo (1995) considerou duas subespécies para Piriqueta viscosa: $P$. viscosa subsp. viscosa e $P$. viscosa subsp. tovarensis Urb., apenas a subespécie típica ocorre no Ceará; $P$. viscosa subsp. tovarensis se diferencia da subespécie típica, principalmente, pela corola amarela ou alaranjada ( $v s$. rosa a rosaescura), sementes oblongo-obovoides, 1,4-1,8 $\times$ 0,9-1,1 mm (vs. sementes estreito-obovoides, 1,6-2,2 × 0,6-0,8 mm) (Arbo 1995).

\section{Turnera L., Sp. Pl. 1: 271. 1753.}

Ervas a arbustos; indumento com tricomas tectores simples, às vezes estrelados e glandulares microcapitados, capitado-estipitados e capitadosésseis. Estípulas rudimentares ou desenvolvidas, às vezes ausentes. Folhas papiráceas a quase coriáceas; nectários extraflorais ausentes ou presentes, neste caso, basilaminares ou peciolares, geralmente discoides. Inflorescências unifloras e solitárias ou plurifloras, em capítulos; brácteas ausentes ou presentes. Flores com pedúnculo livre ou adnato ao pecíolo da folha (flor epífila), às vezes ausente; bractéolas desenvolvidas, opostas, localizadas na base do cálice; pedicelo ausente. Cálice com lacínios triangulares a estreito- 
triangulares, ápice agudo a mucronado. Corola branca, amarela ou laranja, raro salmão, lilás ou rosa. Corona ausente. Filetes livres ou com porção dorso basal discretamente adnata ao tubo floral, às vezes, adnatos pelas margens à unha das pétalas, formando sacos nectaríferos. Cápsulas com epicarpo piloso, às vezes glabro na base. Sementes retas ou curvas; calaza arredondada, obtusa ou proeminente.

Turnera inclui 143 espécies, a maior parte destas distribui-se desde o sul dos Estados Unidos até a Argentina, e apenas duas ocorrem na África (Arbo et al. 2015). No Brasil são registradas 120 espécies, sendo 85 endêmicas, com centros de diversidade localizados no Planalto brasileiro no estado de Goiás, na porção central da Cadeia do Espinhaço em Minas Gerais e na Chapada Diamantina na Bahia (Arbo \& Mazza 2011; BFG 2015). Para o estado do Ceará foram encontradas 15 espécies, associadas principalmente à vegetação da caatinga, cerrado ou tabuleiros litorâneos, em áreas abertas, por vezes alteradas.

\section{Chave de identificação das espécies de Turnera ocorrentes no Ceará}

1. Indumento com tricomas tectores estrelados.

2. Inflorescências uniforas, solitárias; brácteas ausentes; bractéolas subuladas a lanceoladas

2.4. Turnera cearensis

2'. Inflorescências plurifloras, em capítulos; brácteas subcirculares; bractéolas obovadas 2.2. Turnera blanchetiana var. blanchetiana

1'. Indumento com tricomas tectores apenas simples.

3. Nectários extraflorais ausentes.

4. Folhas 4,7-6,3 cm compr.; corola laranja a laranja-avermelhada....... 2.12. Turnera reginae

4'. Folhas 0,5-4,3 cm compr.; corola em outras cores.

5. Folhas ovadas a estreito-ovadas; estípulas rudimentares; indumento com tricomas glandulares capitado-estipitados 2.5. Turnera chamaedrifolia

5'. Folhas obovadas, elíptico, estreito a largo-obovadas; estípulas desenvolvidas, 0,5-4 mm compr.; indumento com tricomas glandulares capitado-sésseis.

6. Corola 6-7 mm compr., amarela ....................... 2.7. Turnera diffusa var. diffusa

6’. Corola 8-14 mm compr., branca, base das pétalas amarela.

2.3. Turnera calyptrocarpa

3'. Nectários extraflorais presentes.

7. Inflorescências plurifloras em capítulos

2.1. Turnera bahiensis var. truncata

7'. Inflorescências unifloras, solitárias, às vezes em racemos no ápice dos ramos.

8. Frutos com epicarpo verrucoso.

9. Indumento com tricomas glandulares capitado-sésseis; folhas com face abaxial tomentoso-hirsuta às vezes vilosa; filetes com porção dorso basal discretamente adnata ao tubo floral 2.10. Turnera odorata

9'. Indumento com tricomas glandulares microcapitados; folhas com face adaxial estrigosa a denso-estrigosa; filetes com margens adnatas a unha das pétalas, formando sacos nectaríferos.

10. Corola branca a branco-azulada

11. Folhas ovadas ou elíptico-ovadas, margens serreado-crenadas e face adaxial estrigosa 2.6.1. Turnera coerulea var. coerulea

11'. Folhas lineares a estreito-ovadas, margens serrilhadas e face adaxial glabra.... 2.6.2. Turnera coerulea var. surinamensis

10'. Corola amarela ou creme.

12. Corola amarela, base das pétalas amarelo-escura

2.13. Turnera scabra

12'. Corola creme, raro amarela, base das pétalas castanho-escura 2.15. Turnera subulata

8'. Frutos com epicarpo liso. 
13. Flores homostilas; sementes lunadas

2.11. Turnera pumilea var. pumilea

13'. Flores heterostilas; sementes obovoides.

14. Folhas com duas faces glabras.

2.8. Turnera guianensis

14'. Folhas com as duas faces pilosas.

15. Caules tomentosos, tricomas glandulares capitado-sésseis; lâmina foliar com face adaxial tomentoso-velutina, face abaxial lanoso-velutina.

2.14. Turnera stachydifolia var. stachydifolia

15'. Caules estrigosos a hirsutos, tricomas glandulares microcapitados; lâmina foliar com face adaxial estrigosa a esparso-pilosa, face abaxial esparso-pilosa a denso-estrigosa.

16. Folhas coriáceas, lâmina ovada, elíptica, largo-elíptica, raro obovada.

2.9.1. Turnera melochioides var. melochioides

16'. Folhas papiráceas, lâmina lanceolada, estreito-elíptica, a linear.

17. Lâmina lanceolada a ovado-lanceolada, margens serreadas a duplamente serreadocrenadas

2.9.3. Turnera melochioides var. latifolia

17'. Lâmina linear, margens subinteiras a serrilhadas.

2.9.2. Turnera melochioides var. arenaria

2.1. Turnera bahiensis var. truncata Arbo, Bonplandia 14(3-4): 134. 2005. Figs. 2j; 4; 9f,g

Arbustos 1-4 m alt.; caules esparso-pilosos a tomentosos, tricomas tectores simples. Estípulas 3-3,5 mm compr. Folhas com pecíolo 1-1,6 cm compr.; nectários extraflorais 2 ou 3 pares,
0,6-0,9 mm diâm.; lâmina 2,2-7,5 × 1,8-3,5 cm, cartácea, ovada a elíptica, base cuneada, ápice agudo, margens serreadas a serreado-crenadas; face adaxial estrigosa, face abaxial denso-estrigosa. Inflorescências em capítulos; brácteas 6-8 $\times$ 5-6 mm, ovadas a estreito-ovadas, 2-4 pares de

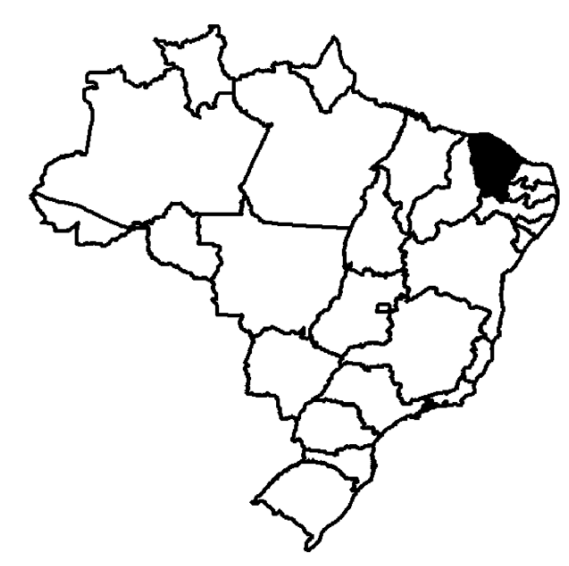

\section{Legenda}

Espécies

- Turnera bahiensis var. truncata

- Turnera blanchetiana var. blanchetiana

- Turnera calyptrocarpa

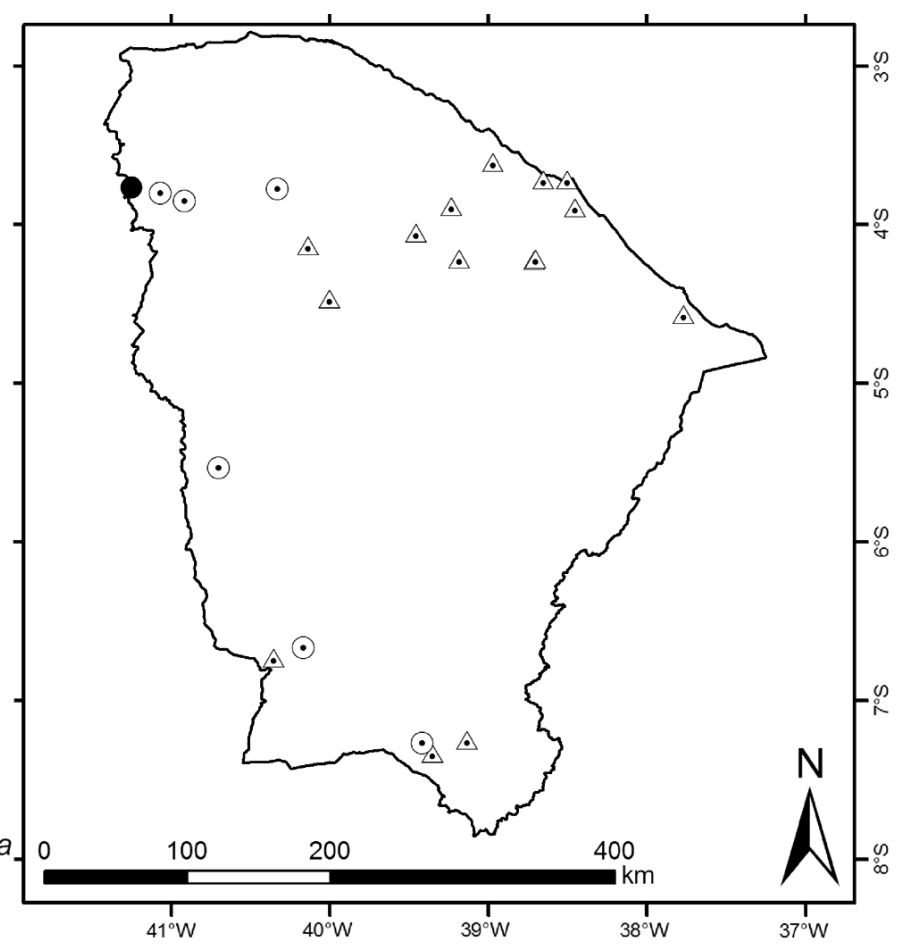

Figura 4 - Distribuição de Turnera bahiensis var. truncata, T. blanchetiana var. blanchetiana e T. calyptrocarpa no estado do Ceará.

Figure 4 - Distribution of Turnera bahiensis var. truncata, T. blanchetiana var. blanchetiana e T. calyptrocarpa in Ceará state. 
nectários, 1-1,2 mm diâm. Flores heterostilas; pedúnculo e pedicelo ausentes; bractéolas 3,5-5 $\mathrm{mm}$ compr., estreito-obovadas, ápice truncado, ligeiramente mucronado. Cálice 9-9,5 mm compr., externamente denso-piloso. Corola 10-11 mm compr., amarela. Filetes $7,5-8 \mathrm{~mm}$ compr. em flores brevistilas, $6-6,5 \mathrm{~mm}$ compr. em flores longistilas, esparso-pilosos, margens ca. $3,5 \mathrm{~mm}$ adnatas à unha das pétalas, formando sacos nectaríferos. Estiletes 2-3 mm compr. em flores brevistilas, ca. $8 \mathrm{~mm}$ compr. em flores longistilas, esparso-pilosos. Cápsulas 7-8 mm diâm.; epicarpo verrucoso, tomentoso-hirsuto. Sementes 2,5-3 × 1,2-1,5 $\mathrm{mm}$, obovoides, ligeiramente curvas, reticuladas; epiderme papilosa; calaza proeminente.

Iconografia: Arbo (2005, Fig. 6a-n: 131, 8a-m:135). Material selecionado: Tianguá, BR-222, Ibiapaba, $3^{\circ} 46^{\prime}$ 'S, $41^{\circ} 15^{\prime}$ 'W, 14.II.1979, fl. e fr., A. Fernandes (EAC 5487).

Material adicional examinado: BRASIL. BAHIA: Barreiras, Ponta d'Água em direção a Coribe/Descoberto, 1343'34"S, 4418'54”W, 457 m, 9.I.2008, fl., A.L. Côrtes et al. 59 (HUEFS). Macaúbas, estrada para Canatiba, Serra Poções, próximo ao alto, $13^{\circ} 1^{\prime} \mathrm{S}$, $42^{\circ} 41^{\prime}$ W, 1.100 m, 18.I.1997, fl. e fr., G. Hatschbach et al. 65966 (CTES, MBM). PIAUII: Caracol, PARNA Serra das Confusões-Serra Grande, 27.III. 2007, fl., $R$. Barros et al. 2868 (HUEFS, IPA).

Ocorre nos estados da Bahia, Ceará e Piauí (BFG 2015). No Ceará foi encontrada em áreas de carrasco, apresentando flores e frutos em fevereiro. Pode ser reconhecida pelas inflorescências em capítulos, com brácteas ovadas a estreito-ovadas e indumento composto apenas por tricomas tectores simples. Assemelha-se a Turnera blanchetiana, a qual se diferencia pelo indumento com tricomas estrelados e brácteas subcirculares. Arbo (2005) considerou duas variedades para Turnera bahiensis: T. bahiensis var. bahiensis e T. bahiensis var. truncata Arbo, apenas esta última ocorre no Ceará. A variedade típica pode ser reconhecida, principalmente, pelas brácteas com ápice agudo e nectários com tamanho igual aos das folhas; enquanto que, Turnera bahiensis var. truncata possui brácteas externas com nectários geralmente maiores que aqueles das folhas, as internas apresentam ápice truncado.

2.2. Turnera blanchetiana Urb. var. blanchetiana, Jahrb. Königl. Bot. Gart. Berlin 2: 130. 1883.

Figs. 2k-m; 4; 9h,i

Arbustos 0,4-2 m alt.; caules esparso-pilosos a tomentosos, tricomas tectores simples e estrelados curtos. Estípulas 1-2 mm compr. Folhas com pecíolo 6-10 mm compr.; nectários extraflorais 1 ou 2 pares, aprox. 0,5 mm diâm.; lâmina 3,3-8 $\times$ $2-3,5 \mathrm{~cm}$, cartácea, ovada a elíptica, base cuneada, ápice agudo, raro obtuso, margens serreadas a serreado-crenadas; face adaxial esparso-pilosa a pilosa, face abaxial tomentosa a velutina. Inflorescências em capítulos; brácteas 5-6,5 × 5-6 mm, côncavas, subcirculares, amplexicaules, nectários ausentes. Flores heterostilas; pedúnculo e pedicelo ausentes; bractéolas ca. $4 \mathrm{~mm}$ compr., obovadas, ápice agudo. Cálice ca. 9,5 mm compr., externamente tomentoso. Corola ca. $18 \mathrm{~mm}$ compr., amarela. Filetes 6-7 mm compr. em flores brevistilas, 3-5 mm compr. em flores longistilas, pilosos, margens ca. $3,5 \mathrm{~mm}$ adnatas à unha das pétalas, formando sacos nectaríferos. Estiletes 2-3 $\mathrm{mm}$ compr. em flores brevistilas, $4-5 \mathrm{~mm}$ compr. em flores longistilas, pilosos. Cápsulas 5-8 mm diâm.; epicarpo verrucoso, denso-hirsuto. Sementes 2,5-3,3 × 1,3-1,6 mm, obovoides, ligeiramente curvas, estriado-reticuladas; epiderme papilosa; calaza proeminente.

Iconografia: Arbo (2005, Fig. 9a-n: 137).

Material selecionado: Aiuaba, distrito de Barra, Estação Ecológica de Aiuaba, 640'S, 40¹0'W, 400 m, 4.II.1997, fl. e fr., M.A. Figueiredo et al. 680 (CTES, EAC).

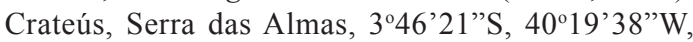
620 m, 25.II.2002, fl. e fr., F.S. Araújo 1283 (HUEFS). Crato, FLONA do Araripe, $7^{\circ} 16^{\prime} \mathrm{S}, 39^{\circ} 25^{\prime} \mathrm{W}, 25 . \mathrm{II} .1999$, fl. e fr., L.W. Lima-Verde 1305 (EAC). Novo Oriente, Jaburuna-sul, planalto da Ibiapaba, 5'32'S, 40'42'W, 17.V.1994, fl. e fr., F.S. Araújo 707 (EAC). Tianguá, 348'S, 414'W, 15.III.1978, fl. e fr., A. Salgado-Odilon 33-24 (RB). Ubajara, Jaburuna-sul, planalto da Ibiapaba, 351'S, 4055'W, 830 m, 21.II.1995, fl. e fr., F.S. Araújo 1102 (CTES, EAC 22920).

Ocorre na Bolívia, Paraguai, além do Brasil, onde pode ser encontrada no Nordeste (Bahia, Ceará, Paraíba, Pernambuco, Piauí e Rio Grande do Norte), Centro-Oeste (Mato Grosso do Sul e Mato Grosso) e Sudeste (Minas Gerais) (BFG 2015). No Ceará foi registrada na caatinga e carrasco, em áreas ensolaradas de vegetação aberta. Floresce e frutifica durante o ano todo. Pode ser reconhecida pelo indumento com tricomas tectores estrelados curtos, inflorescências em capítulos e brácteas subcirculares, amplexicaules. Assemelha-se a Turnera cearensis e T. bahiensis, a primeira se diferencia pelas inflorescências unifloras, sem brácteas, com pedúnculos desenvolvidos; a segunda pode ser diferenciada pelas brácteas ovadas a estreito-ovadas e indumento composto apenas por tricomas tectores simples. Arbo (2005) reconheceu duas variedades para Turnera blanchetiana: T. 
blanchetiana var. blanchetiana e T. blanchetiana var. subspicata Urb., apenas a variedade típica ocorre no Ceará. T. blanchetiana var. subspicata se caracteriza pelas inflorescências em racemos espiciformes, enquanto que na variedade típica, são capítulos.

2.3. Turnera calyptrocarpa Urb., Jahrb. Königl. Bot. Gart. Berlin 2: 128. $1883 . \quad$ Figs. 2n,o; 4; 9 j Arbustos 0,4-1 m alt.; caules esparsoestrigosos a glabros, tricomas tectores simples e glandulares capitado-sésseis. Estípulas 2,5-4 $\mathrm{mm}$ compr. Folhas com pecíolo 2-6 $\mathrm{mm}$ compr.; nectários extraflorais ausentes; lâmina 0,5-3,5 × 0,5-2,5 cm, cartácea, obovada, estreito a largoobovada, base cuneada, ápice obtuso, raro agudo, margens serreadas a serreado-crenadas; face adaxial esparso-estrigosa, face abaxial denso-pilosa a tomentosa. Inflorescências unifloras, solitárias; brácteas ausentes. Flores heterostilas; pedúnculo 1-3 mm compr., livre do pecíolo; bractéolas 3-5 mm compr., estreito-obovadas a espatuladas, ápice obtuso; pedicelo ausente. Cálice 4-6 mm compr., externamente esparso a denso-hirsuto. Corola 8-14 $\mathrm{mm}$ compr., branca, base das pétalas amarela. Filetes 6-7 mm compr. em flores brevistilas, 3-4 $\mathrm{mm}$ compr. em flores longistilas, esparso-pilosos, porção dorso basal discretamente adnata ao tubo floral. Estiletes 1,5-2,5 mm compr. em flores brevistilas, 2,5-4 mm compr. em flores longistilas, glabros. Cápsulas 5-6 mm diâm.; epicarpo verrucoso, hirsuto. Sementes 1,5-2 × ca. $1 \mathrm{~mm}$, obovoides, retas, reticuladas; epiderme papilosa; calaza ligeiramente proeminente.

Iconografia: Arbo (2000, Fig. 16a-h: 46).

Material selecionado: Acarape, localidade Garapa, 413'27'’S, 3842'30”'W, 11.IV.2005, fl., E. Silveira (EAC 34897). Aiuaba, Estação Ecológica de Aiuaba, 644'S, $40^{\circ} 21^{\prime}$ 'W, 620 m, 20.V.1998, fl. e fr., L.W. Lima-Verde \& I.M. Andrade 930 (CTES, EAC). Aracati, BR-304, próximo ao $\mathrm{km} 61$, córrego Ubarana, 434' $\mathrm{S}, 37^{\circ} 46^{\prime} \mathrm{W}$, 11.III.1979, fl. e fr., A. Fernandes (EAC 5709). Barbalha, sítio Arqueológico, $7^{\circ} 20^{\prime} \mathrm{S}, 39^{\circ} 21^{\prime} \mathrm{W}, 18 . \mathrm{IX} .1992$, fl. e fr., L.P. Felix (EAC 19094). Caridade, Fazenda Feijão, 4¹3'S, 39¹1'W, 11.III.1990, fl. e fr., B. Freitas (EAC 16754). Caucaia, Parque Botânico, $3^{\circ} 43^{\prime} \mathrm{S}, 38^{\circ} 39^{\prime} \mathrm{W}$, 8.V.1998, fl. e fr., E.B. Souza (EAC 26428). Eusébio, 3053'24'S, 38²7'2"W, 3.IV.2005, fl. e fr., A.S.F. Castro 1570 (EAC). Fortaleza, terreno vizinho ao EAC, $3^{\circ} 43^{\prime}$ 'S, $38^{\circ} 30^{\prime}$ W, 4.II.1955, fl. e fr., A. Fernandes (EAC 1091). General Sampaio, 43'10"S, 39²7'16”'W, 28.IV.2007, fl. e fr., M.F. Moró 61 (EAC, HUVA). Missão Velha, sítio de pedras fossilizadas, $7^{\circ} 15^{\prime} \mathrm{S}, 39^{\circ} 8^{\prime} \mathrm{W}, 18$. IX.1992, f1. e fr., E. Nunes (EAC 18801). Pentecoste, Serrote de Tamanduá, $3^{\circ} 53^{\prime} \mathrm{S}, 39^{\circ} 14^{\prime} \mathrm{W}, 31 . \mathrm{III} .2001$, fl. e fr.,
A. Andrade (EAC 30580). Reriutaba, estrada para Guaraciaba do Norte, 4'8'S, 40³4'W, 25.V.1981, fl. e fr., A. Fernandes \& P. Martins (EAC 10312). Santa Quitéria, Fazenda Intan de Cima, Serra do Pajé, 4²8'S, $40^{\circ} 0$ 'W, 8.VII.1995, fl. e fr., L.W. Lima-Verde (EAC 25565). São Gonçalo do Amarante, Estação Ecológica do Pecém, 336'26”'s, 3858' '6”W, 1.VIII.2010, fl. e fr., A.S.F. Castro 2374 (EAC).

Ocorre em todos estados nordestinos, até Minas Gerais (BFG 2015). No Ceará foi encontrada na caatinga, cerrado e tabuleiros litorâneos, geralmente associada a áreas abertas, crescendo em substratos arenosos ou argilosos. Floresce e frutifica durante o ano todo. Pode ser reconhecida pelas estípulas desenvolvidas (2,5-4 mm compr.), folhas obovadas, bractéolas estreito-obovadas a espatuladas e corola branca com base amarela. Assemelha-se a Turnera diffusa, a qual se diferencia pelas bractéolas lineares e corola amarela.

2.4. Turnera cearensis Urb., Jahrb. Königl. Bot. Gart. Berlin 2: 100. $1883 . \quad$ Figs. 5a; 6; 9k

Arbustos 0,7-2,5 m alt.; caules pilosos a tomentosos, tricomas tectores simples e estrelados. Estípulas 1,5-2(-3) mm compr. Folhas com pecíolo 3-7 mm compr.; nectários extraflorais $1-2(-3)$ pares, $0,5-1 \mathrm{~mm}$ diâm.; lâmina $1,4-7,5(-8,6)$ $\times 0,5-3,4 \mathrm{~cm}$, cartácea, ovada, largo-ovada a elíptica, base arredondada, ápice agudo a obtuso, margens serreadas, serreado-crenadas a crenadas, às vezes com nectários nos dentes basais; face adaxial esparso a denso-pilosa, às vezes velutina, face abaxial tomentoso-velutina. Inflorescências unifloras, solitárias; brácteas ausentes. Flores heterostilas; pedúnculo 1-3 mm compr., livre do pecíolo; bractéolas 5-10 mm compr., subuladas a lanceoladas, ápice agudo; pedicelo ausente. Cálice 10-15 mm compr., hirsuto a tomentosohirsuto. Corola 12-20 mm compr., amarela. Filetes 6-8 mm compr. em flores brevistilas, 4,5-6 mm compr. em flores longistilas, pilosos, margens $3-4,5 \mathrm{~mm}$ adnatas à unha das pétalas, formando sacos nectaríferos. Estiletes 2,5-3 mm de compr. em flores brevistilas, 5-7 mm compr. em flores longistilas, pilosos. Cápsulas 7-10 mm diâm.; epicarpo verrucoso, denso hirsuto. Sementes 2-3,7 $\times 1,5-1,7 \mathrm{~mm}$, obovoides, ligeiramente curvas, estriado-reticuladas; epiderme papilosa; calaza proeminente.

Iconografia: Arbo (2005, Fig. 12a-j: 143).

Material selecionado: Guaraciaba do Norte, $4^{\circ} 10^{\prime}$ 'S, 404''W, 15.VI.1979, fl. e fr., A. Fernandes (EAC 6575). Senador Pompeu, Serrote do Patu, 5 35 'S, $39^{\circ} 22^{\prime}$ W, 18.I.1995, fl. e fr., E.B. Souza \& A.R. Bezerra 

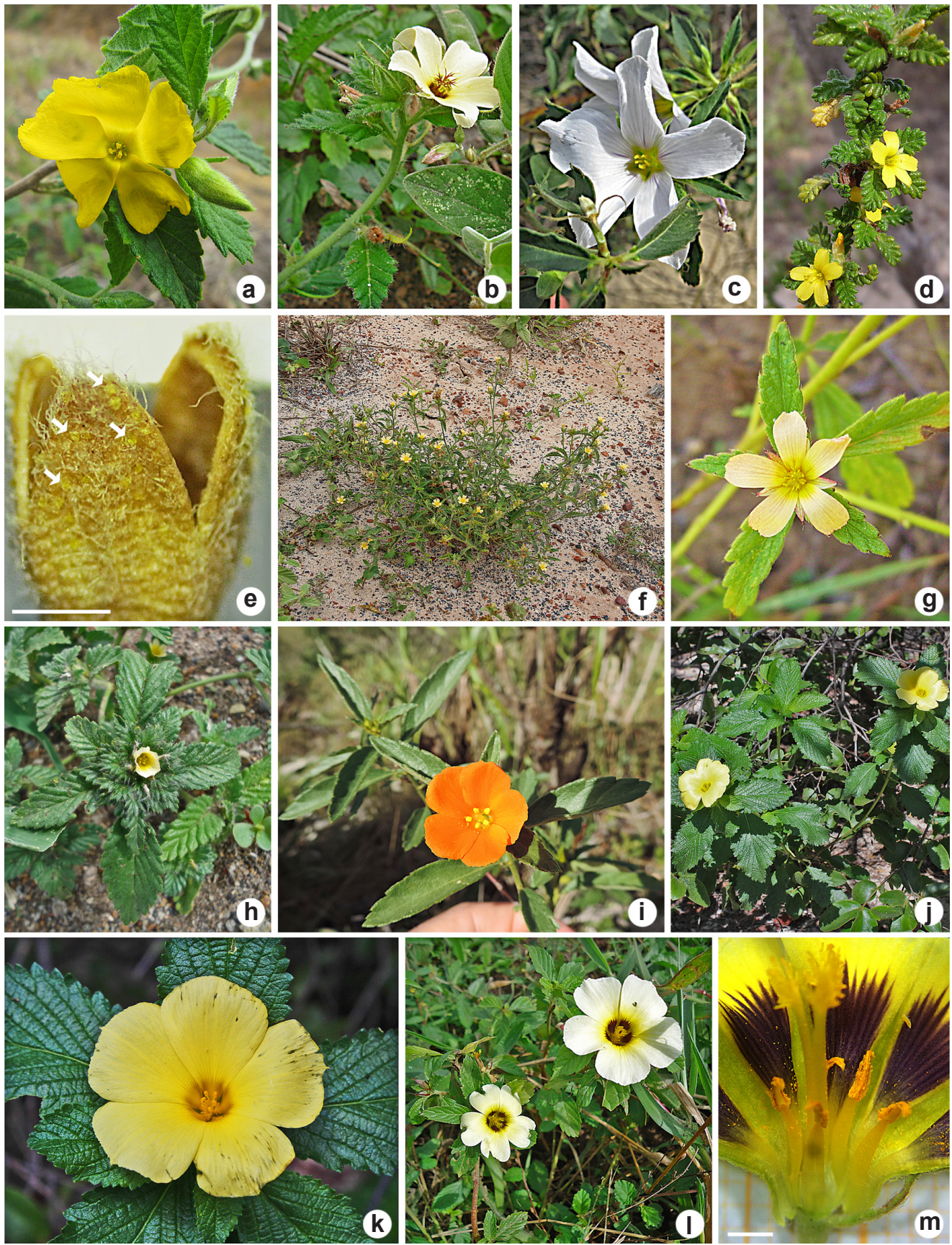

Figura 5 - a. Turnera cearensis - ramo com botão e flor; b. T. chamaedrifolia - ramo com botão e flor; c. T. coerulea var. coerulea - ramo com flores; d,e. T. diffusa var. diffusa-d. ramo com flores; e. fruto evidenciando epicarpo e indumento, setas brancas indicando tricomas capitado-sésseis (escala $=1 \mathrm{~mm}) ; \mathrm{f}, \mathrm{g}$. T. melochioides var. latifolia - f. hábito; g. ramo com flor; h. T. pumilea var. pumilea - ramo com flor; i. T. reginae - ramo com flor; j,k. T. scabra-j. hábito; k. ramo com flor; 1,m. T. subulata - 1. ramos com flores; $\mathrm{m}$. flor longistila evidenciando a porção interna do tubo floral, com cinco estames, pistilo e base das pétalas sem corona (escala =1 mm). (a,b,e,f,h,l,m: L. Rocha; c: R.G.V. Camacho; d,g: A. Alves; i. L.Jales; j,k: I.M. Souza). Figure 5 - a. Turnera cearensis - branch with flower bud and flower; b. T. chamaedrifolia - branch with flower bud and flower; c. T. coerulea var. coerulea - branch with flowers; d,e. T. diffusa var. diffusa - d. branch with flower; e. fruit showing epicarp and indumentum, white arrows indicate sessile-capitate trichomes $(\mathrm{scale}=1 \mathrm{~mm}) ; \mathrm{fg}$. T. melochioides var. latifolia $-\mathrm{f}$. habit; g. branch with flower; $\mathrm{h}$. T. pumilea var. pumilea - branch with flower; i. T. reginae - branch with flower; j,k. T. scabra - j. habit; k. branch with flower; 1,m. T. subulata-1. branches with flower; $\mathrm{m}$. longstyled flower showing the inner face of the floral tube, with five stamens, pistil and base of petals without corona (scale = $1 \mathrm{~mm}) .(\mathrm{a}, \mathrm{b}, \mathrm{e}, \mathrm{f}, \mathrm{h}, 1, \mathrm{~m}: \mathrm{L}$. Rocha; c: R.G.V. Camacho; d,g: A. Alves; i. L. Jales; j,k: I.M. Souza). 
(EAC 21904). Tianguá, Serra Grande, 348'S, 414'W, 4.IX.2003, fl. e fr., A. Fernandes (EAC 33028). Ubajara, Jaburuna-sul, planalto de Ibiapaba, $3^{\circ} 51^{\prime} \mathrm{S}, 40^{\circ} 55^{\prime} \mathrm{W}$, 830 m, 27.I.1996, fl. e fr., F.S. Araújo 1152 (CTES, EAC, UEC). Viçosa do Ceará, Cocalzinho, Chapada da Ibiapaba, 3³3'44"S, 415'32"W, 5.I.1987, fl. e fr., $A$. Fernandes (EAC 14873).

Ocorre em todos estados nordestinos, até Minas Gerais (BFG 2015). No Ceará, foi encontrada no carrasco e cerrado, em áreas fechadas ou abertas e ensolaradas, às vezes alteradas; cresce em substratos argilosos. Floresce e frutifica durante o ano todo. Pode ser reconhecida pelas flores solitárias desprovidas de brácteas, pedúnculos livres do pecíolo e corola amarela. Assemelha-se a Turnera blanchetiana, a qual se diferencia pelas flores reunidas em capítulos bracteosos.

2.5. Turnera chamaedrifolia Cambess., Fl. Bras. Merid. 2(16): 221. 1829.

Figs. 5b; 6; 91

Subarbustos ou ervas 0,3-1,5 m de alt.; caules esparso a denso-hirsutos, tricomas tectores simples e glandulares capitado-estipitados. Estípulas rudimentares. Folhas com pecíolo 2-7 mm compr.; nectários extraflorais ausentes; lâmina 0,8-4,3 × 0,4 2,2 cm, cartácea a papirácea, ovada a estreito-ovada, base cuneada a atenuada, ápice agudo, margens serreadas a serreado-crenadas; face adaxial hirsuta, face abaxial hirsuta a denso-hirsuta. Inflorescências unifloras, solitárias; brácteas ausentes. Flores heterostilas; pedúnculo 3-7 $\mathrm{mm}$ compr., livre do pecíolo; bractéolas 5-7(-10) mm compr., subuladas, ápice agudo; pedicelo ausente. Cálice 6-12 mm compr., externamente esparso a denso-hirsuto. Corola 9-13 mm compr., creme, base das pétalas vinho. Filetes 4-5 mm compr. em flores brevistilas, 2,5-3 mm compr. em flores longistilas, glabros, porção dorso basal discretamente adnata ao tubo floral. Estiletes 2-3 mm compr. em flores brevistilas, 3,5-4 mm compr. em flores longistilas, glabros. Cápsulas 4-6 mm diâm.; epicarpo verrucoso, hirsuto. Sementes ca. 1,8 $\times 1 \mathrm{~mm}$, obovoides, retas, reticuladas; epiderme lisa; calaza obtusa.

Iconografia: Arbo (2000, Fig. 20a-f: 69).

Material examinado: Crato, Barreiro Grande, Chapada do Araripe, 7¹4'3”'S, 39²4'34”W, 19.I.2005, fl. e fr., F.S. Cavalcanti 932 (EAC).
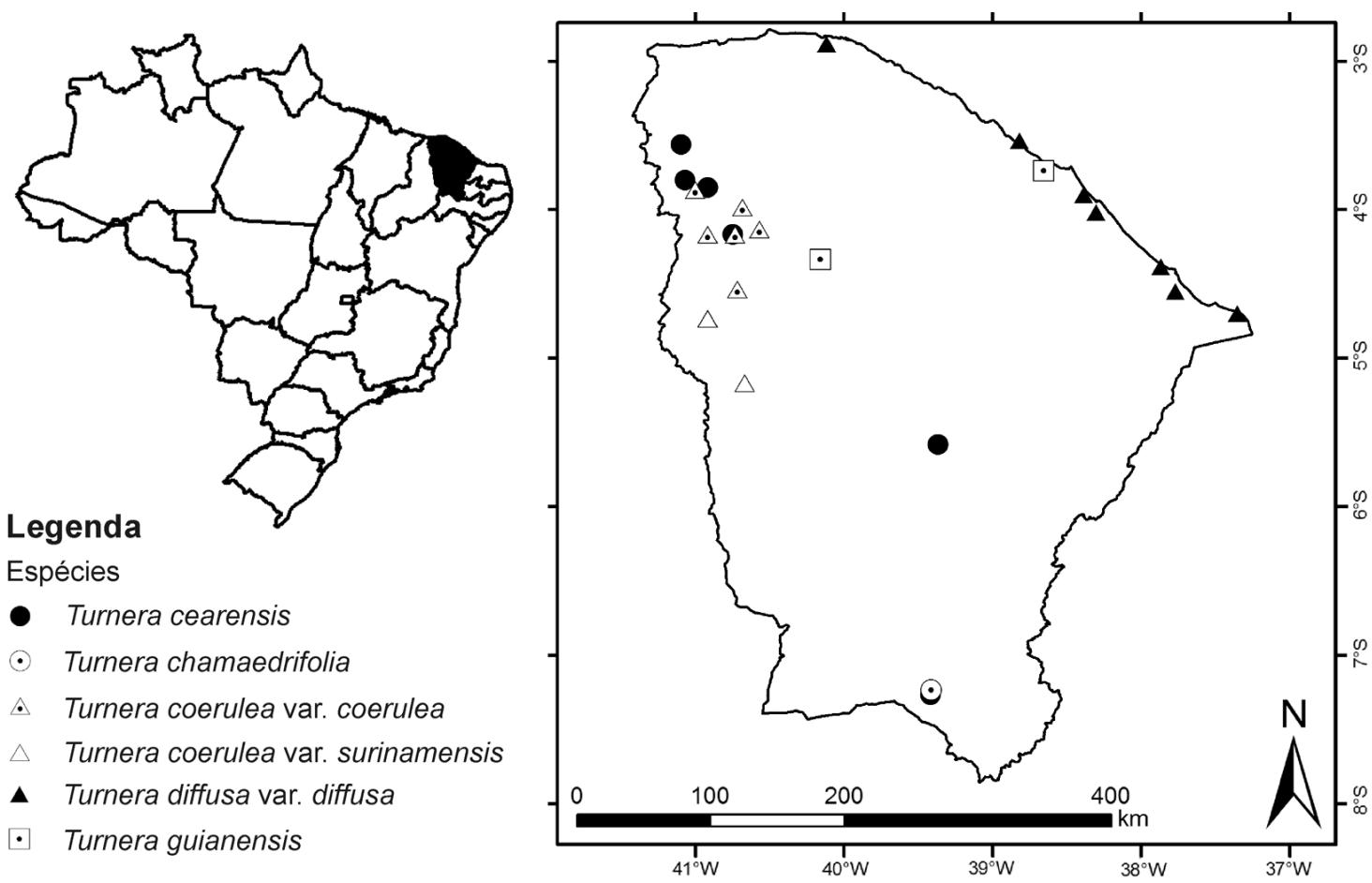

Figura 6 - Distribuição de Turnera cearensis, T. chamaedrifolia, T. coerulea var. coerulea, T. coerulea var. surinamensis, T. diffusa var. diffusa e T. guianensis no estado do Ceará.

Figure 6 - Distribution of Turnera cearensis, T. chamaedrifolia, T. coerulea var. coerulea, T. coerulea var. surinamensis, T. diffusa var. diffusa and T. guianensis in Ceará state. 
Material adicional examinado: BRASIL. BAHIA: Feira de Santana, Estrada do Feijão, lado esquerdo, 30.IV.2012, fl., L. Rocha \& I. Souza 376 (CTES, HUEFS). Morro do Chapéu, localidade Boca do Cedro, margem direita da BA-052, para Utinga, $11^{\circ} 55^{\prime} \mathrm{S}$, 41ํㄷ' 'W, 28.I.2013, fl., L. Rocha \& B.S. Gregório 387 (HUEFS, RB). Pindobaçu, Serra da Fumaça, trilha para serra, 40³9'55'S, 40²0'34'W, 16.XII.2008, fl. e fr., L.A. Sousa 220 (HUEFS).

Ocorre em todos estados nordestinos, além de Minas Gerais e Rio de Janeiro (BFG 2015). No Ceará é conhecida por apenas um espécime, encontrado na caatinga. Pode ser reconhecida pelo indumento com tricomas capitado-estipitados, pedúnculos desenvolvidos e flores com corola creme e base das pétalas vinho. Assemelha-se a Turnera calyptrocapa, T. caatingana Arbo e T. asymmetrica Arbo; a primeira se diferencia pelas folhas obovadas e pétalas brancas com base amarela; as duas últimas são endêmicas da Bahia, T. caatingana se diferencia pelas folhas e pétalas geralmente maiores (2,5-10 cm compr. e 1,3-1,7 cm compr., respectivamente), além dos ramos com ápice denso-hirsuto; T. asymmetrica se diferencia pelas pétalas amarelas e bractéolas ovadas e assimétricas.

2.6.1. Turnera coerulea DC. var. coerulea, Prodr. 3: 346. 1828 . Figs. 5c; 6; 9m

Subarbustos a arbustos $0,2-1,5 \mathrm{~m}$ alt.; caules esparso a denso-estrigosos, tricomas tectores simples e glandulares microcapitados. Estípulas rudimentares. Folhas com pecíolo 4-8 mm compr.; nectários extraflorais 1 par, 0,8-1,5 mm diâm.; lâmina $1,5-7 \times 0,5-2 \mathrm{~cm}$, papirácea, elíptica, ovada a estreito-ovada, base cuneada ou arredondada, ápice agudo, margens serreadas a discretamente serreadas; face adaxial esparsoestrigosa, face abaxial estrigosa. Inflorescências unifloras, solitárias ou reunidas no ápice dos ramos; brácteas ausentes. Flores heterostilas, epífilas; pedúnculo 2,5-5 $\mathrm{mm}$ compr., adnato ao pecíolo; bractéolas 4-10 mm compr., subuladas, ápice agudo; pedicelo ausente. Cálice 1,5-2 cm compr., externamente estrigoso. Corola 20-40 mm compr., branca a branco-azulada, base das pétalas amarela com linhas azul-escuras. Filetes 10-12 mm compr. em flores brevistilas, 5-6 mm compr. em flores longistilas, pilosos, margens $3-3,5 \mathrm{~mm}$ adnatas à unha das pétalas, formando sacos nectaríferos. Estiletes 4-6 mm compr. em flores brevistilas, 1-1,1 cm compr. em flores longistilas, glabros ou pilosos. Cápsulas 5-7 $\mathrm{mm}$ diâm.; epicarpo verrucoso, estrigoso. Sementes 2,2-2,7 × 0,7-1 mm, obovoides, ligeiramente curvas, reticuladas; epiderme lisa; calaza obtusa.

Iconografia: Arbo (2005, Fig. 40a-f: 202).

Material selecionado: Carnaubal, Planalto da Ibiapaba, $4^{\circ} 10^{\prime}$ 'S, 405' 'W, 803 m, 30.IV.2010, fl. e fr., E.B. Souza et al. 1839 (HUEFS, HUVA). Crateús, Serra das Almas, $5^{\circ} 10^{\prime} \mathrm{S}, 40^{\circ} 40^{\prime} \mathrm{W}, 650-700 \mathrm{~m}$, 26.III.2002, fl. e fr., F.S. Araújo \& L.C. Girão 1389 (HUEFS). Granja, CE-362, ca. $10 \mathrm{~km}$ de Granja em direção a Martinópole, $3^{\circ} 11$ '15"S, 4044'38'W, 21.V.2015, fl. e fr., E.B. Souza et al. 3429 (EAC). Guaraciaba do Norte, $4^{\circ} 10^{\prime} \mathrm{S}, 40^{\circ} 44^{\prime} \mathrm{W}$, fl. e fr., 27.II.1981, A. Fernandes \& P. Martins (EAC 9809). Ipueiras, Buriti, 4³2'S, 4043'W, 27.VI.2011, fl. e fr., A.S.F. Castro 2523 (EAC). Pacujá, 359'S, 4041'W, 18.V.2007, fl. e fr., I.M. Andrade 3017 (HUEFS, HUVA). Reriutaba, Juré, 48'S, 40³4'W, 25.V.1981, fl. e fr., $A$. Fernandes (EAC 10301). Ubajara, Planalto da Ibiapaba,

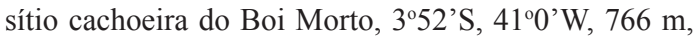
28.IV.2010, fl. e fr., E.B. Souza et al. 1820 (HUEFS, HUVA).

Distribui-se no México, Bolívia e Brasil, além do sul dos Estados Unidos, para onde é conhecido apenas um antigo exemplar (Arbo 2005). No Brasil ocorre no Sudeste (Minas Gerais), em quase todos os estados das regiões Norte (exceto Acre e Rondônia), Nordeste (exceto Alagoas, Pernambuco e Rio Grande do Norte) e CentroOeste (exceto Distrito Federal) (BFG 2015). No Ceará foi encontrada no carrasco. Floresce e frutifica durante o ano todo. Pode ser reconhecida pelas flores com pétalas brancas a branco-azuladas com base amarela e linhas azul-escuras, além das margens das folhas, geralmente com dentes largos e irregulares, diferencia-se de $T$. coerulea var. surinamensis pelas folhas geralmente largas e estrigosas. Assemelha-se a Turnera candida Arbo, não registrada no Ceará, a qual se diferencia pelas folhas elípticas regularmente serreadas e flores homostilas (Rocha \& Rapini 2016).

2.6.2. Turnera coerulea var. surinamensis (Urb.) Arbo \& Fernández. Bonplandia 9(1-2): 95-102. 1996.

Fig. 6

Subarbustos a arbustos 0,2-1,5 m alt.; caules esparso a denso-estrigosos, tricomas tectores simples e glandulares microcapitados. Estípulas rudimentares. Folhas com pecíolo 3-7 mm compr.; nectários extraflorais 1 par, ca. 0,8 mm diâm.; lâmina 1,8-8,5 ×0,3-1,4(-2) cm, linear a estreitoovada, base cuneada ou arredondada, ápice agudo, margens serrilhadas; face adaxial glabra, face abaxial glabra ou com pilosa apenas nas nervuras. Inflorescências unifloras, solitárias ou reunidas no ápice dos ramos; brácteas ausentes. Flores 
heterostilas, epífilas; pedúnculo ca. $2 \mathrm{~mm}$ compr., adnato ao pecíolo; bractéolas 4-9 $\mathrm{mm}$ compr., subuladas, ápice agudo; pedicelo ausente. Cálice 10-20 mm compr., externamente estrigoso. Corola 15-20 mm compr., branca a branco-azulada, base das pétalas amarela com linhas azul-escuras. Filetes 10-13 mm compr. em flores brevistilas, $5-8 \mathrm{~mm}$ compr. em flores longistilas, pilosos, margens 3-6 $\mathrm{mm}$ adnatas à unha das pétalas, formando sacos nectaríferos. Estiletes 3-6 mm compr. em flores brevistilas, $7-10 \mathrm{~mm}$ compr. em flores longistilas, glabros ou pilosos. Cápsulas 5-6 mm diâm.; epicarpo verrucoso, estrigoso. Sementes 2-2,5 × ca. $1 \mathrm{~mm}$, obovoides, ligeiramente curvas, reticuladas; epiderme lisa; calaza obtusa.

Iconografia: Arbo (2005, Fig. 40g-m: 202).

Material selecionado: Crateús, Ibiapaba sul, $5^{\circ} 10^{\prime} \mathrm{S}$, $40^{\circ} 40^{\prime} \mathrm{W}, 650$ m, 20.V.1997, M.A. Figueiredo 804 (CTES). Poranga, Ibiapaba Norte, $4^{\circ} 44^{\prime} \mathrm{S}, 40^{\circ} 55^{\prime} \mathrm{W}$, 20.V.1997, fl. e fr., M.A. Figueiredo (CTES, EAC 25609).

Ocorre no México, Suriname, Guianas e Brasil, onde é registrada no Centro-Oeste (Goiás), Norte (Amazonas, Amapá, Pará, Roraima, Tocantins) e Nordeste (exceto Alagoas, Paraíba e Rio Grande do Norte). No Ceará foi encontrada com flores e frutos em maio, no carrasco e cerradão, associada a áreas alagadiças. Diferenciase da variedade típica principalmente pelas folhas geralmente estreitas e esparso-pilosas.

2.7. Turnera diffusa Willd. ex Schult. var. diffusa, Syst. Veg. 6: 679. $1820 . \quad$ Figs. 5d,e; 6; 9n Arbustos 0,3-1,5 m alt.; caules esparsopilosos a tomentosos, tricomas tectores simples e glandulares capitado-sésseis. Estípulas 0,5$1,5(-3) \mathrm{mm}$ compr. Folhas geralmente reunidas em braquiblastos terminais, pecíolo até $4 \mathrm{~mm}$ compr.; nectários extraflorais ausentes; lâmina $0,5-2 \times 0,2-0,8 \mathrm{~cm}$, cartácea, obovada a elípticoobovada, base cuneada a atenuada, ápice obtuso ou agudo, margens crenadas a serreadas; face adaxial hirsuta a tomentoso-hirsuta, face abaxial tomentosa, às vezes cinérea. Inflorescências unifloras, solitárias, às vezes reunidas no ápice dos ramos; brácteas ausentes. Flores heterostilas; pedúnculo até $1 \mathrm{~mm}$ compr., parcialmente adnato ao pecíolo; bractéolas 3-5 $\mathrm{mm}$ compr., lineares, ápice agudo; pedicelo ausente. Cálice 4,5-5 mm compr., externamente hirsuto a tomentoso-hirsuto. Corola 6-7 mm compr., amarela. Filetes 3-5 mm compr. em flores brevistilas, 2,5-3 mm compr. em flores longistilas, pilosos, porção dorso basal discretamente adnata ao tubo floral. Estiletes
1,8-2,5 mm compr. em flores brevistilas, 3-4 mm compr. em flores longistilas, pilosos. Cápsulas 3-4 mm diâm.; epicarpo discretamente verrucoso, hirsuto. Sementes 1,5-1,7 × 1-1,2 mm, obovoides, curvas; reticuladas; epiderme lisa; calaza obtusa. Iconografia: Arbo (2000, 17a-f: 50).

Material selecionado: Acaraú, Caiçara, $2^{\circ} 53^{\prime}$ 'S, $40^{\circ} 7$ 'W, 5.IV.1984, fl. e fr., A. Fernandes \& Matos (EAC 12436). Aquiraz, 354'S, 38²3'W, 22.IV.1990, fl. e fr., A. Fernandes et al. (EAC 16314). Aracati, BR-304, próximo ao $\mathrm{km}$ 61, córrego Ubarana, 4³3'S, 37²6'W, 11.III.1979, fl. e fr., A. Fernandes (EAC 5708). Icapuí, Ponta Grossa, 442'S, 37²1'W, 29.IV.2000, fl. e fr., Montenegro et al. 15 (EAC). Pindoretama, $4^{\circ} 1^{\prime}$ 'S, $38^{\circ} 18^{\prime} \mathrm{W}, 23$.VIII.1989, fl. e fr., A. Fernandes (EAC 16172). São Gonçalo do Amarante Pecém, 332'S, $38^{\circ} 49^{\prime}$ W, 6.IV.2008, fl. e fr., M.F. Moro \& E. TameirãoNeto 385 (EAC).

Ocorre no sul dos Estados Unidos, México, Antilhas e América do Sul (Arbo 2000). No Brasil, é registrada na maioria dos estados nordestinos (exceto Maranhão), até Minas Gerais (BFG 2015). No Ceará foi encontrada associada aos tabuleiros litorâneos, crescendo sobre substratos arenosos, em áreas abertas, por vezes, antropizadas. Floresce e frutifica durante o ano todo. Pode ser reconhecida pelas folhas geralmente reunidas em braquiblastos terminais, flores com pétalas amarelas e sementes curvas, reticuladas. Assemelha-se a Turnera calyptrocarpa, a qual pode ser diferenciada pelas flores com pétalas brancas e base amarela. Arbo (2000) considerou duas variedades: T. diffusa var. diffusa e T. diffusa var. aphrodisiaca (Ward) Urb., apenas a variedade típica ocorre no Ceará. Turnera diffusa var. aphrodisiaca ocorre apenas no México e parte da América Central, apresenta pedúnculos 1-2 mm compr., e folhas, bractéolas e pétalas glabras, enquanto que a variedade típica apresenta pedúnculos menores (até $1 \mathrm{~mm}$ compr.) e folhas, bractéolas e pétalas pilosos.

2.8. Turnera guianensis Aubl., Hist. Pl. Guiane 1: 291. 1775. Fig. 6

Ervas 20-42(-68) cm alt.; caules glabros ou pubérulos, neste caso, com tricomas tectores simples. Estípulas rudimentares. Folhas sésseis; nectários extraflorais até 1 par, $0,5-0,8 \mathrm{~mm}$ diâm.; lâmina 3,5-61 ×0,5-5 mm, papirácea, lanceolada a linear, base cuneada, ápice agudo, margens inteiras ou serrilhadas; as duas faces glabras. Inflorescências unifloras, reunidas no ápice dos ramos; folhas floríferas reduzidas, bractiformes. Flores heterostilas, epífilas; pedúnculo 1-4 $\mathrm{mm}$ compr., adnato ao pecíolo; bractéolas $2-3 \mathrm{~mm}$ 
compr., lineares, ápice agudo; pedicelo ausente. Cálice 5-10 mm compr., externamente glabro, às vezes raros tricomas no ápice dos lacínios. Corola 15-25 mm compr., amarela a creme, com linhas avermelhadas. Filetes 4-7 mm compr. em flores brevistilas, 3-5 mm compr. em flores longistilas, glabros, porção dorso basal $0,4-0,8 \mathrm{~mm}$ adnata ao tubo floral. Estiletes 1,5-2,5 $\mathrm{mm}$ compr. em flores brevistilas, 4-7 $\mathrm{mm}$ compr. em flores longistilas, glabros ou pilosos. Cápsulas 2-3 mm diâm.; epicarpo liso, glabro ou esparso-piloso no ápice. Sementes ca. $2 \times 1 \mathrm{~mm}$, obovoides, quase retas, reticuladas; epiderme com cera epicuticular bastoniforme; calaza proeminente.

Iconografia: Arbo (2008, Fig. 32a-l: 169).

Material selecionado: Caucaia, Parque Botânico, 3\%44'10”S, 38³9'11'”, 29.I.1998, fl. e fr., A. Fernandes (EAC 25744). Santa Quitéria, Fazenda Bálsamo, 4¹9'55'S, 409'24”'W, 6.VII.1956, fl. e fr., A. Fernandes (EAC 1613).

Ocorre na Venezuela, Guianas, Trinidad e Brasil, onde é registrada nas Regiões Norte (Roraima) e Nordeste (Ceará) (Arbo 2008, 2017). No Ceará, foi encontrada nos tabuleiros litorâneos e caatinga, com flores e frutos nos meses de janeiro e julho. Pode ser reconhecida pelos ramos cilíndricos, folhas sésseis, lanceoladas a lineares, glabras e cálice externamente glabro, às vezes, raros tricomas no ápice dos lacínios. Assemelha-se a Turnera subnuda Urb., não registrada no Ceará, a qual se diferencia, principalmente, pelas folhas filiformes e cálice externamente piloso. Medidas baseadas em Arbo (2008).

2.9.1. Turnera melochioides Cambess. var. melochioides, Fl. Bras. Merid. 2(16): 159 (219). 1829.

Fig. 7

Subarbustos a arbustos 0,3-1,3 m alt.; caules estrigosos, tricomas tectores simples e glandulares microcapitados. Estípulas rudimentares. Folhas com pecíolo 2-6 mm compr.; nectários extraflorais 1 par, até $1 \mathrm{~mm}$ diâm.; lâmina 1-6 ×0,4-1,2 cm, coriácea, ovada, elíptica, elíptica, largo-elíptica, raro obovada, base atenuada a cuneada, ápice obtuso, às vezes agudo, margens serreado-crenadas; face adaxial estrigosa, face abaxial denso-estrigosa. Inflorescências unifloras a plurifloras, em racemos terminais; folhas floríferas reduzidas, bractiformes.

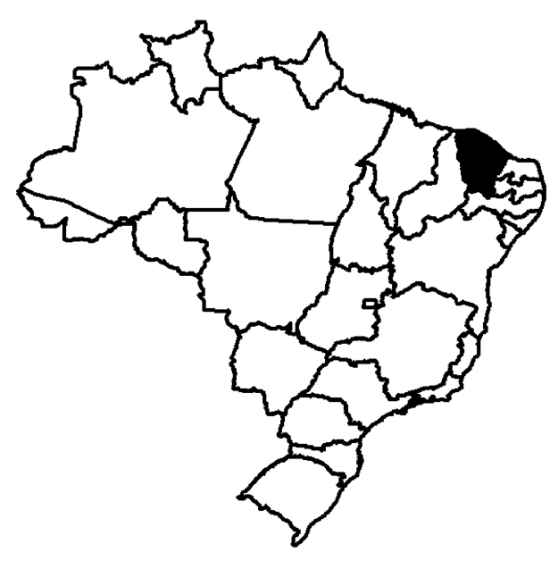

\section{Legenda}

Espécies

Turnera melochioides var. arenaria

- Turnera melochioides var. latifolia

Turnera melochioides var. melochioides.

$\checkmark$ Turnera pumilea

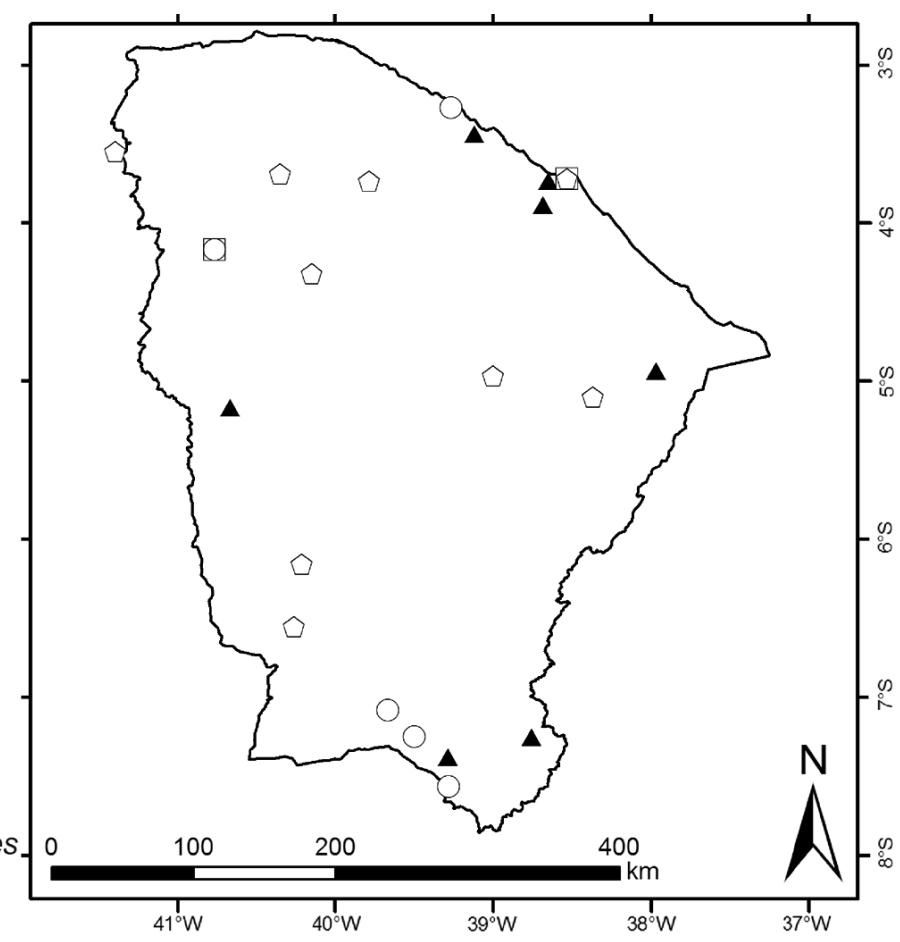

Figura 7 - Distribuição de Turnera melochioides var. arenaria, T. melochioides var. latifolia, T. melochioides var. melochioides e T. pumilea var. pumilea no estado do Ceará.

Figure 7 - Distribution of Turnera melochioides var. arenaria, T. melochioides var. latifolia, T. melochioides var. melochioides and T. pumilea var. pumilea in Ceará state. 
Flores heterostilas, epífilas; pedúnculo 1-3 $\mathrm{mm}$ compr., adnato ao pecíolo; bractéolas 2-5 $\mathrm{mm}$ compr., subuladas, ápice agudo; pedicelo ausente. Cálice 6-9 $\mathrm{mm}$ compr., externamente hirsuto a tomentoso-hirsuto. Corola 7-10 mm compr., amarela a creme. Filetes $5-5,5 \mathrm{~mm}$ compr. em flores brevistilas, 2,5-4,5 mm compr. em flores longistilas, glabros, porção dorso basal discretamente adnata ao tubo floral. Estiletes ca. 2,5 $\mathrm{mm}$ compr. em flores brevistilas, $4-5 \mathrm{~mm}$ compr. em flores longistilas, ápice piloso. Cápsulas 4-6 $\mathrm{mm}$ diâm.; epicarpo liso, hirsuto. Sementes 2-2,5 $\times 0,8-1,2 \mathrm{~mm}$, obovoides, ligeiramente curvas, reticuladas; epiderme papilosa; calaza proeminente. Iconografia: Arbo (2008, Fig. 53a-m: 221).

Material selecionado: Crato, $12 \mathrm{~km}$ sudoeste da cidade na estrada para Exu (PE), Serra do Araripe, $7^{\circ} 14^{\prime} 55^{\prime}$ 'S, 39'29'53"W, ca. 700 m, 30.VII.1997, fl. e fr., W. Thomas et al. 11692 (ALCB, CEPEC, CTES, MBM, SPF). Guaraciaba do Norte, Planalto da Ibiapaba, $4^{\circ} 10^{\prime}$ 'S, 4046’W, 18.VII.1992, fl. e fr., A. Fernandes \& Matos (EAC 20290). Jardim, Sítio Cotovelo, $7^{\circ} 34^{\prime}$ S , 39¹7'W, 1.VIII.2000, fl. e fr., L.W. Lima-Verde (EAC 31471). Nova Olinda, Sítio Sozinho, $7^{\circ} 5^{\prime}$ 'S, 3940'W, 6.V.2006, fl. e fr., J.T. Souza et al. (EAC 39499). Trairi, próximo à Estrada Flexeiras, $3^{\circ} 16^{\prime}$ 'S, 39¹6'W, 23.V.1999, fl. e fr., L.K. Matias 156 (EAC).

Ruderal, distribui-se do Brasil ao NE da Bolívia e NE do Paraguai (Arbo 2008). No Brasil, ocorre no Nordeste (exceto Sergipe, Paraíba e Rio Grande do Norte), Centro-Oeste (exceto Distrito Federal), Norte (apenas Pará, Rondônia e Tocantins) e Sudeste (apenas Minas Gerais) (BFG 2015). No Ceará foi encontrada na caatinga, carrasco, cerrado, floresta ombrófila e tabuleiros litorâneos, em áreas abertas, às vezes antropizadas, como margens de estradas e trilhas; cresce em substratos argilosos vermelhos, argilo-pedregosos e arenosos. Floresce e frutifica durante o ano todo. Pode ser reconhecida pelos caules estrigosos, flores geralmente reunidas em racemos terminais e corola totalmente amarela a creme, às vezes base amareloescura. Assemelha a Turnera stachydifolia, que se diferencia pelos caules denso-lanosos, com tricomas glandulares capitado-sésseis e folhas com as duas faces lanoso-tomentosas. Quando secos, os espécimes de Turnera melochioides var. melochioides podem ser confundidos com T. opifera Mart., uma espécie que não ocorre no Ceará, a qual se diferencia principalmente pelas flores com pétalas maiores (9,5-21,5 mm compr.), dispostas em racemos paniculiformes.

Além das variedades Turnera melochioides var. melochioides, T. melochioides var. arenaria e $T$. melochioides var. latifolia, Arbo (2008) reconheceu T. melochioies var. rugosa Arbo. De modo geral, as variedades podem ser diferenciadas pela forma e coloração das folhas: T. melochioides var. melochioides apresenta folhas coriáceas, ovadas, elípticas, largo-elípticas, raro obovadas, castanhoescuras, quando secas. Turnera melochioides var. arenaria e T. melochioides var. latifolia apresentam folhas papiráceas e verde-oliva claro, quando secas, mas diferenciam-se pela forma: a primeira apresenta folhas lineares, com margens subinteiras a serrilhadas; a segunda possui folhas lanceoladas a ovado-lanceoladas, com margens serreadas a duplamente serreado-crenadas. Turnera melochioies var. rugosa caracteriza-se pelas folhas coriáceas, marrom-escuras quando secas, mas principalmente, pelo epicarpo às vezes rugoso.

2.9.2. Turnera melochioides var. arenaria Urb., Jahrb. Königl. Bot. Gart. Berlin 2: 115. 1883.

Fig. 7

Subarbustos a arbustos $0,3-1,3 \mathrm{~m}$ alt.; caules hirsutos, tricomas tectores simples e glandulares microcapitados. Estípulas rudimentares. Folhas com pecíolo 0,5-5 mm compr.; nectários extraflorais ausentes ou 1 par, neste caso, até $1 \mathrm{~mm}$ diâm.; lâmina 2-5,5 × 1,1-2 cm, papirácea, linear, base atenuada, ápice agudo, subinteiras a serrilhadas; as duas faces esparso-pilosas. Inflorescências unifloras a plurifloras, em racemos abreviados; folhas floríferas reduzidas, bractiformes. Flores heterostilas, epífilas; pedúnculo $0,5-1 \mathrm{~mm}$ compr., adnato ao pecíolo; bractéolas $2-7 \mathrm{~mm}$ compr., filiformes, ápice agudo, às vezes mucronado; pedicelo ausente. Cálice 5-7 $\mathrm{mm}$ compr., externamente hirsuto a tomentoso-hirsuto. Corola 7-10 mm compr., amarela a creme, às vezes base das pétalas amarelo-escura. Filetes 3,5-7 mm compr. em flores brevistilas, 3-4 mm compr. em flores longistilas, glabros, porção dorso basal discretamente adnata ao tubo floral. Estiletes ca. 2,5 $\mathrm{mm}$ compr. em flores brevistilas, 5-5,5 $\mathrm{mm}$ compr. em flores longistilas, ápice piloso. Cápsulas 4-6 mm diâm.; epicarpo liso, hirsuto. Sementes 1,5-2,5 $\times 0,5-1 \mathrm{~mm}$, obovoides, ligeiramente curvas, reticuladas; epiderme papilosa; calaza proeminente. Iconografia: Arbo (2008, Fig. 54a-c, i: 224).

Material selecionado: Fortaleza, Campus do Pici, 343'S, 38²3'W, 14.VIII.1989, fl. e fr., M.F. Mata (EAC 13511B). Guaraciaba do Norte, $4^{\circ} 10^{\prime} \mathrm{S}, 40^{\circ} 46^{\prime} \mathrm{W}$, 5.III.1981, fl. e fr., P. Martins (EAC 9847).

Ruderal, ocorre no NE da Bolívia e Brasil, neste último é registrada no Centro-Oeste (Mato 
Grosso), Norte (Amapá, Pará, Tocantins) e Nordeste (Bahia, Ceará, Maranhão, Piauí, Sergipe) (BFG 2015). No Ceará foi encontrada na caatinga arbórea e carrasco. Floresce e frutifica provavelmente durante o ano todo. Turnera melochioides var. arenaria pode ser reconhecida pelas inflorescências em racemos abreviados, folhas esparso-pilosas, papiráceas, lineares, verde-oliva claro quando secas, com margens subinteiras ou serrilhadas.

2.9.3. Turnera melochioides var. latifolia Urb., Jahrb. Königl. Bot. Gart. Berlin 2: 116. 1883.

Figs. 5f,g; 7; 9o

Ervas ou subarbustos 30-90 cm alt.; caules estrigosos a hirsutos, tricomas tectores simples e glandulares microcapitados. Estípulas rudimentares. Folhas com pecíolo 2-6 $\mathrm{mm}$ compr.; nectários extraflorais 2 pares, até 1 mm diâm.; lâmina 2-6 × 0,8-2,5 cm, papirácea a coriácea, lanceoladas a ovado-lanceoladas, base atenuada, ápice agudo margens serreadas a duplamente serreado-crenadas; face adaxial estrigosa ou esparso-hirsuta, face abaxial hirsuta. Inflorescências unifloras ou plurifloras, em racemos terminais; folhas floríferas reduzidas, bractiformes. Flores heterostilas, epífilas; pedúnculo 1-2 mm compr., adnato ao pecíolo; bractéolas 5-6,5 $\mathrm{mm}$ compr., lineares, ápice agudo, às vezes mucronado; pedicelo ausente. Cálice 5-8 mm compr., externamente hirsuto a tomentoso-hirsuto. Corola 6-11,5 mm compr., totalmente amarela a creme, às vezes base das pétalas amarelo-escura. Filetes 5-5,5 mm compr. em flores brevistilas, 3,5-4,5 mm compr. em flores longistilas, glabros, porção dorso basal discretamente adnata ao tubo floral. Estiletes 2-3 $\mathrm{mm}$ compr. em flores brevistilas, 4-5,5 mm compr. em flores longistilas, ápice esparso-piloso. Cápsulas 5-6 mm diâm.; epicarpo liso, hirsuto. Sementes 1,7-2 × 0,7-1 $\mathrm{mm}$, obovoides, ligeiramente curvas, reticuladas; epiderme papilosa; calaza proeminente.

Iconografia: Arbo (2008, Fig. 54d-h: 224).

Material selecionado: Barbalha, FLONA AraripeApodi, trilha para a nascente dos Cocos, $7^{\circ} 22^{\prime} 45^{\prime} \mathrm{S}$, 39 $17^{\prime} 7^{\prime}$ 'W, 771 m, 4.VIII.2011, fl. e fr, E.V.R. Ferreira et al 294 (CTES, HVASF). Caucaia, parque botânico, 344'S, 38³9'W, 8.V.1998, fl. e fl., A.A. Melo (EAC 26503). Crateús, Ibiapaba sul-Mambira, sertão de Crateús, 510'S, 4040'W, 460 m, 20.V.1997, fl. e fr., L.W. Lima-Verde (CTES, EAC 25613). Fortaleza, Praia de Sabiaguaba, 343'S, 38² $32^{\prime} \mathrm{W}$, 4.IX.2002, fl. e fr., A.S.F. Castro (EAC 32265). Maranguape, São Benedito, 353'S, 3841'W, 27.IV.1997, fl. e fr., A.S.F. Castro (EAC 24901). Mauriti, estrada para Freixeiras,
7¹5'16”S, 3845'18”'W, 526 m, 29.IV.2009, J.R. Maciel et al. 1085 (CTES, HVASF). Paraipaba, APA das Dunas de Lagoinha, 326'S, 39²'W, 28.II.2004, fl. e fr., D.V. Azevedo 3 (EAC). Russas, próximo à cidade, 45' $\mathrm{S}$, $37^{\circ} 58^{\prime}$ W, 25.V.1941, fl. e fr., P. Bezerra (EAC 274).

Ruderal, ocorre no NE da Bolívia e Brasil, neste último é registrada no Centro-Oeste (Mato Grosso), Norte (Amazonas, Pará) e Nordeste (exceto Alagoas) (BFG 2015). No Ceará foi encontrada na caatinga, em áreas abertas, às vezes antropizadas; cresce em substratos arenosos, argilosos vermelhos ou argilo-pedresosos. Floresce e frutifica praticamente durante o ano inteiro. Pode ser reconhecida principalmente pelas folhas lanceoladas a ovado-lanceoladas, com face adaxial estrigosa ou esparso-hirsuta, e margens serrilhadas, serreadas a duplamente serreado-crenadas; quando secos, os espécimes adquirem a coloração verdeoliva claro.

2.10. Turnera odorata Rich., Actes Soc. Hist. Nat. Paris 1: 107. 1792.

Arbustos 0,3-4 m alt.; caules tomentosohirsutos, principalmente no ápice dos ramos, tricomas tectores simples e glandulares capitadosésseis, dourados. Estípulas 0,3-1,4 mm compr., subuladas. Folhas com pecíolo 2-9 mm compr.; nectários extraflorais 1-3 pares, 0,3-1 mm diâm.; lâmina 3-8,5(-103) × 1,5-4,2 cm, papirácea, ovada ou elíptica, base atenuada ou cuneada, ápice agudo, margens simples a duplamente serreadas; face adaxial hirsuta a esparso-hirsuta, face abaxial tomentoso-hirsuta às vezes vilosa. Inflorescências unifloras, solitárias; brácteas ausentes. Flores heterostilas; pedúnculo 0,5-2 mm compr., adnato apenas na base ao pecíolo; bractéolas 3-8 $\mathrm{mm}$ de compr., lineares, elípticas ou estreito-obovadas, ápice agudo; pedicelo ausente. Cálice 8-10 mm compr., externamente glabro ou esparso-piloso. Corola 9-12 mm compr., amarelo-clara ou amareloalaranjada. Filetes 5-7 $\mathrm{mm}$ compr. em fores brevistilas, 3-4,5 mm compr. em flores longistilas, pilosos, porção dorso basal discretamente adnata ao tubo floral. Estiletes 1,5-3 $\mathrm{mm}$ compr. em flores brevistilas, 6-7 $\mathrm{mm}$ compr. em flores longistilas, hirsutos. Cápsulas 4-8 mm diâm.; epicarpo verrucoso a ligeiramente tuberculado, piloso. Sementes 1,3-2,1 × 1-1,5 mm, obovoides, reticuladas; epiderme papilosa; calaza proeminente. Iconografia: Arbo (2000, Fig. 3a-i: 14).

Material examinado: Local e município não determinados, $1.860 \mathrm{~m}$, bot. e fr., Freire-Allemão (R 91301). Município não determinando, Serra de Maranguape, X.1910, Ule 9041 (IPA). 
Ocorre na Colombia, Venezuela, Guiana, Guiana Francesa, Suriname, Trindade e Tobago, e Regiões Norte (exceto Acre), Nordeste (apenas Ceará e Maranhão) e Centro-Oeste (exceto Brasília) do Brasil (Arbo 2000; BFG 2015). É conhecida para o Ceará através de dois antigos registros, o único com localidade citada provém da Serra de Maranguape, provavelmente no norte do estado, na região metropolitana de Fortaleza. Turnera odorata pode ser reconhecida pelas folhas hirsutas às vezes com face abaxial vilosa, geralmente com tricomas glandulares capitadosésseis dourados, além da corola amarelo-clara ou amarelo-alaranjada. Assemelha-se a Turnera aromatica Arbo, não ocorrente do Ceará, pode ser diferenciada principalmente pelos esparsos tricomas glandulares capitado-sésseis amarelopálidos e cálice externamente viloso ou tomentoso. Medidas baseadas em Arbo (2000).

2.11. Turnera pumilea $\mathrm{L}$. var. pumilea, Syst. Nat., ed. 10, 2: 965. 1759 . Figs. 5h; 7; 9p,q

Ervas ca. $25 \mathrm{~cm}$ alt.; caules hirsutos a densohirsutos, principalmente no ápice dos ramos, tricomas tectores simples. Estípulas rudimentares. Folhas geralmente reunidas em rosetas terminais; pecíolo 5-7 $\mathrm{mm}$ compr.; nectários extraflorais até 2 pares, ca. 0,5 mm diâm.; lâmina 1,1-2,7 × $0,7-1,4 \mathrm{~cm}$, papirácea, ovada a elíptico-ovada, base cuneada, ápice agudo, margens simples a duplamente serreadas; face adaxial hirsuta a esparso-hirsuta, face abaxial tomentoso-hirsuta, principalmente nas nervuras. Inflorescências unifloras, solitárias, às vezes reunidas no ápice dos ramos; brácteas ausentes. Flores homostilas, epífilas; pedúnculo ca. $3 \mathrm{~mm}$ compr., adnato ao pecíolo; bractéolas 5-8 $\mathrm{mm}$ de compr., lineares, ápice agudo; pedicelo ausente. Cálice 5-7 $\mathrm{mm}$ compr., externamente viloso, principalmente nos lacínios. Corola 5,5-8 mm compr., amarela, base das pétalas às vezes amarelo-escura. Filetes 4-4,5 mm compr., glabros, porção dorso basal discretamente adnata ao tubo floral. Estiletes ca. 4 mm compr.; glabros. Cápsulas 4-5 mm diâm.; epicarpo liso, denso-hirsuto apenas no ápice. Sementes 1,5-2 $\times 1 \mathrm{~mm}$, lunadas, reticuladas; epiderme com cera epicuticular filiforme; calaza proeminente.

Iconografia: Arbo (2008, Fig. 66a-g: 257).

Material selecionado: Aiuaba, Estação Ecológica de Aiuaba, Malhada, 6³3'3,8'S, 40¹5'48,4'W, 490 m, 26.II.1997, fl. e fr., L.W. Lima-Verde 471 (EAC). Arneiroz, a $20 \mathrm{~km}$ de Tauá em direção ao município,
609'25'S, 40¹2'50'W, 500 m, 20.III.2002, fl. e fr., V.C. Souza; H. Lorenzi \& A. Fernandes 28764 (CTES, ESA). Crateús, Grajal, Serra das Almas, 280 m, 27.I.2002, fl. e fr., F.S. Araújo 1336 (EAC, HUEFS). Fortaleza, Campus do Pici, 343'S, 38³2'W, 2.I.1976, fl. e fr., A. Fernandes (EAC 2677). Irauçuba, 344'S, 3947'W, VI.2007, fl. e fr., C.D.S. Pessoa 89 (EAC). Morada Nova, fazenda Serraria, Baixo Jaguaribe, 56'S, 38²2'W, 25.IV.1997, fl. e fr., L.W. Lima-Verde 689 (EAC). Quixadá, Fazenda Não Me Deixes, 458'S, 390'W, 16.III.2000, fl. e fr., R.C. Costa 70 (EAC). Santa Quitéria, Fazenda Itatiaia, 4¹9'S, 409'W, 26.IV.1984, fl. e fr., A. Fernandes (CTES, EAC 12463). Sobral, 341'10’'S, 40²0'59’'W, III.1995, fl. e fr., M.F. Mata 120 (HUVA). Viçosa do Ceará, Sítio Engenho Velho, área de litígio CE-PI, 3³2'44”S, 41'23'39'W, 332 m, 29.IV.2010, fl. e fr., E.M. Marreira et al. 720 (HUEFS, HUVA).

Ruderal, distribui-se desde o México, Ilhas do Caribe até o norte da Argentina (Arbo 2008). No Brasil, ocorre no Centro-Oeste (exceto Distrito Federal), Nordeste (exceto Alagoas), Norte (Pará, Roraima, Tocantins) e Sudeste (Minas Gerais, Rio de Janeiro) (BFG 2015). No Ceará foi encontrada na caatinga e tabuleiros, em áreas abertas, por vezes antropizadas; crescendo em substratos argilosos e arenosos. Floresce e frutifica durante o ano todo. Trata-se de uma espécie morfologicamente única no gênero, a disposição das folhas em rosetas terminais e, principalmente, as sementes lunadas a tornam inconfundível com outras espécies. Arbo (2008) considerou duas variedades: T. pumilea var. pumilea e T. pumilea var. piauhyensis Urb., apenas a primeira ocorre no Ceará. A variedade típica pode ser reconhecida pelas flores homostilas, enquanto T. pumilea var. piauhyensis apresenta flores heterostilas.

2.12. Turnera reginae Arbo, Bonplandia 14(3-4): 156. 2005.

Fig. $5 \mathrm{i}$

Ervas ou subarbustos $30-35 \mathrm{~cm}$ alt., caules denso-pilosos a tomentosos, tricomas tectores simples. Estípulas rudimentares. Folhas com pecíolo 4,5-6 mm compr.; nectários extraflorais ausentes; lâmina 4,7-6,3 × 1,8-2,3 cm, cartácea, estreito-ovada, base atenuada, ápice agudo, margens serreado-crenadas; face adaxial esparsopilosa, face abaxial denso-pilosa. Inflorescências unifloras, reunidas em racemos terminais; brácteas $2-2,2 \times 8,5-9,5 \mathrm{~mm}$, elípticas a estreito-ovadas, nectários ausentes. Flores heterostilas; pedúnculo 6-7 mm compr., parcialmente adnato ao pecíolo, às vezes à base da lâmina foliar, porção apical livre; bractéolas ca. 1,5 cm compr., elípticas, foliáceas, ápice agudo; pedicelo ausente. Cálice 
18-20 mm compr., externamente estrigoso. Corola 28-30 mm compr., laranja a laranja-avermelhada. Filetes ca $13,5 \mathrm{~mm}$ compr. em flores brevistilas, ca. $8,5 \mathrm{~mm}$ compr. em flores longistilas, glabros, margens $5-5,5 \mathrm{~mm}$ adnatas à unha das pétalas, formando sacos nectaríferos; em flores brevistilas, porção livre coerente formando um tubo estaminal. Estiletes ca. $8 \mathrm{~mm}$ compr. em flores brevistilas, 11$12 \mathrm{~mm}$ compr. em flores longistilas, porção basal denso-pilosa. Cápsulas e sementes desconhecidos. Iconografia: Arbo (2005, Fig. 19a-f: 157).

Material examinado: BRASIL. MARANHÃO: Balsas, Projeto Geral de Balsas, Lote 16, $8^{\circ} 36^{\prime}$ 'S, 46 $46^{\circ}$ 'W, 470 m, 9.XI.1996, R.C. Oliveira 392 (holótipo CEN; isótipo CTES); (Condomínio Kissy), 8³6’S, 46² $43^{\prime} \mathrm{W}, 470$ m, 20.XI.1995, M.A. Silva et al. 3255 (parátipo CEN).

Rara, ocorre no Maranhão e Piauí (Arbo \& Giulietti 2009), está sendo registrada pela primeira vez para o estado do Ceará, mas apenas através de registro fotográfico, realizado no município de Viçosa do Ceará, onde ocorre associada à vegetação do cerrado. Turnera reginae pode ser reconhecida pelas folhas sem nectários, corola laranja e bractéolas foliáceas. Assemelha-se ligeiramente a Turnera longiflora Cambess., a qual não ocorre no Ceará, e que se diferencia pelos estames livres entre si, com porção dorso-basal discretamente adnata ao tubo floral, além da corola vermelha e base amarela. Descrição baseada em Arbo (2005).

2.13. Turnera scabra Millsp., Publ. Field Columb. Mus., Bot. Ser. 2(1): 77. 1900. Figs. 5j,k; 8; 9r

Ervas $70-80 \mathrm{~cm}$ alt.; caules estrigosos a tomentosos, tricomas tectores simples. Estípulas rudimentares. Folhas com pecíolo 3,5-11 mm compr.; nectários extraflorais 1 par, ca. $0,8 \mathrm{~mm}$ diâm.; lâmina 1,5-4,6 × 0,8-2,8 cm, papirácea, ovada a elíptico-ovada, às vezes lanceolada, base cuneada ou atenuada, ápice agudo, margens simples a duplamente serreado-crenadas; as duas faces denso-estrigosas, raro velutinas. Inflorescências unifloras, solitárias ou reunidas no ápice dos ramos; brácteas ausentes. Flores heterostilas, epífilas; pedúnculo 3-6 $\mathrm{mm}$ compr., adnato ao pecíolo; bractéolas 6-8 $\mathrm{mm}$ compr., subuladas, ápice agudo; pedicelo ausente. Cálice $13-15 \mathrm{~mm}$ compr.; externamente denso-estrigoso. Corola 17-21 mm compr., amarela, base das pétalas amarelo-escura. Filetes 8-9 mm compr. em flores brevistilas, 3-4 mm compr. em flores longistilas, glabros, margens $1-1,5 \mathrm{~mm}$ adnatas unha das pétalas, formando sacos nectaríferos. Estiletes 4-5 $\mathrm{mm}$ compr. em flores brevistilas, $7-8 \mathrm{~mm}$ compr. em flores longistilas, glabros. Cápsulas 4-6 mm diâm.; epicarpo verrucoso, denso-piloso. Sementes 2-2,5 × ca. $1 \mathrm{~mm}$, estreito-obovoides, ligeiramente curvas, reticuladas; epiderme lisa; calaza obtusa. Iconografia: Arbo (2005, Fig. 56a-e: 249).

Material selecionado: Aiuaba, Estação Ecológica de Aiuaba, 6 ${ }^{\circ} 34^{\prime}$ 'S, 407'W, 4.VI.1997, fl. e fr., E.O. Barros 61 (EAC). Icapuí, APA Ponta Grossa, 442’45”'S, 37³1'12"W, 9.IX.2000, fl. e fr., G. Ximenes et al. (EAC). Oros, Cinco Barras, 6¹0'S, 3857’W, 190 m, 9.VII.1984, fl. e fr., F.C.F Silva 205 (RB).

Material adicional examinado: BRASIL. RIO GRANDE DO NORTE: Natal, Parque Estadual Dunas do Natal, dunas após a Trilha da Geologia, 1.VII.2009, fl. e fr., J.L. Costa-Lima \& D. Cardoso 174 (HUEFS, MBM). ALAGOAS: Campo Alegre, Fazenda Mineiro, margem do Jequiá, 9 $47^{\prime} 55^{\prime}$ ”S, 361' 92 ”'W, 11.XI.2000, fl. e fr., I.A. Bayma 430 (HUEFS).

Ruderal, distribui-se do México, América Central, Ilhas do Caribe, Colômbia, Venezuela, Brasil e Guianas. No Brasil ocorre no Norte (exceto Rondônia e Tocantins), Nordeste (exceto Pernambuco) e Sudeste (apenas Espírito Santo) (Arbo 2005; BGF 2015). No Ceará foi encontrada na caatinga e tabuleiros litorâneos, crescendo em áreas abertas, sobre substrato quartzito, calcário e arenoso. Floresce e frutifica provavelmente durante o ano todo. Pode ser reconhecida pelas flores heterostilas, com pedúnculo adnato ao pecíolo, pétalas amarelas e base amarelo-escura. Assemelha-se a Turnera subulata e T. orientalis (Urb.) Arbo; a primeira diferencia-se pelas pétalas creme, raro amarelas, com base castanho-escura e sementes ligeiramente maiores; a segunda, não ocorre no Ceará, diferencia-se principalmente pelas flores homostilas.

2.14. Turnera stachydifolia Urb. \& Rolfe var. stachydifolia, Jahrb. Königl. Bot. Gart. Berlin 2: 122. 1883.

Fig. 8

Arbustos ca. $1 \mathrm{~m}$ alt.; caules tomentosos, tricomas tectores simples e glandulares capitadosésseis. Estípulas rudimentares. Folhas com pecíolo 3-4 mm compr.; nectários extraflorais 1 par, 0,30,5 mm diâm.; lâmina 1,7-3,2 × 7-1,5 cm, cartácea, elíptica ou obovada, base cuneada ou atenuada, ápice obtuso a ligeiramente agudo, margens duplamente serreado-crenadas; face adaxial tomentoso-velutina, face abaxial lanoso-velutina. Inflorescências unifloras, reunidas em racemos terminais; folhas floríferas reduzidas, bractiformes. Flores heterostilas, epífilas; pedúnculo $1,5-2,5 \mathrm{~mm}$ compr., adnato ao pecíolo; bractéolas $2,5-5 \mathrm{~mm}$ compr., lineares, ápice agudo; pedicelo ausente. 
Cálice ca. 5 mm compr., externamente densolanoso. Corola 5-6 mm compr., amarela. Filetes ca. 3,2 mm compr. em flores brevistilas, hirsutos apenas na base, porção dorso basal discretamente adnata ao tubo floral. Estiletes 1,2-1,5 mm compr. em flores brevistilas, pilosos. Flores longistilas não observadas. Cápsulas ca. 4 mm diâm.; epicarpo liso, hirsuto. Sementes 1,9-2 × ca. 0,9 $\mathrm{mm}$, obovoides, ligeiramente curvas, reticuladas; epiderme papilosa; calaza proeminente. Iconografia: Arbo (2008, Fig. 76a-n: 289).

Material examinado: São Benedito, localidade Faveira, 4'2'S, 4051'W, 27.V.1981, fl., A. Fernandes (EAC 10387).

Aparentemente endêmica do Nordeste brasileiro, ocorre nos estados do Ceará, Piauí e Bahia (BFG 2015). No Ceará é conhecida por apenas um espécime, encontrado no cerrado. Pode ser reconhecida pelo indumento tomentoso, com tricomas glandulares capitado-sésseis, folhas com face adaxial tomentoso-velutina e face abaxial lanoso-velutina, apresentando nervuras profundamente impressas na face adaxial, tornando-a bulada. Quando secos, os espécimes são verde-opacos. Para esta espécie, Arbo (2008) reconheceu duas variedades: T. stachydifolia var. stachydifolia e T. stachydifolia var. flexuosa Urb. Apenas a variedade típica ocorre no Ceará, a qual apresenta ramos retos e tomentosos, enquanto que T. stachydifolia var. flexuosa diferencia-se pelos ramos em zique-zague e lanosos. As medidas de fruto e sementes estão baseadas em Arbo (2008).

2.15. Turnera subulata Sm., Cycl. 36(2): 441. 1817.

Figs. $51, \mathrm{~m} ; 8 ; 9 \mathrm{~s}$

Ervas a subarbustos $40-70 \mathrm{~cm}$ alt.; caules estrigosos a denso-estrigosos, tricomas simples e glandulares microcapitados. Estípulas ca. 0,5 mm compr. Folhas com pecíolo 9-15 mm compr.; nectários extraflorais 1 par, 0,5-0,7 mm diâm.; lâmina 2,5-9 × 1,2-6 cm, papirácea, ovada, elíptica, obovada, às vezes lanceolada, base cuneada, ápice agudo, margens simples a duplamente serreadas; as duas faces estrigosas, face abaxial às vezes densoestrigosa. Inflorescências unifloras, solitárias a reunidas no ápice dos ramos; brácteas ausentes. Flores heterostilas, epífilas; pedúnculo 4-10 mm compr., adnato ao pecíolo; bractéolas 5-13 mm compr., subuladas, ápice agudo; pedicelo ausente. Cálice 12-17 mm compr., externamente densoestrigoso. Corola 17-30 mm compr., creme, raro amarela, base das pétalas castanho-escura. Filetes

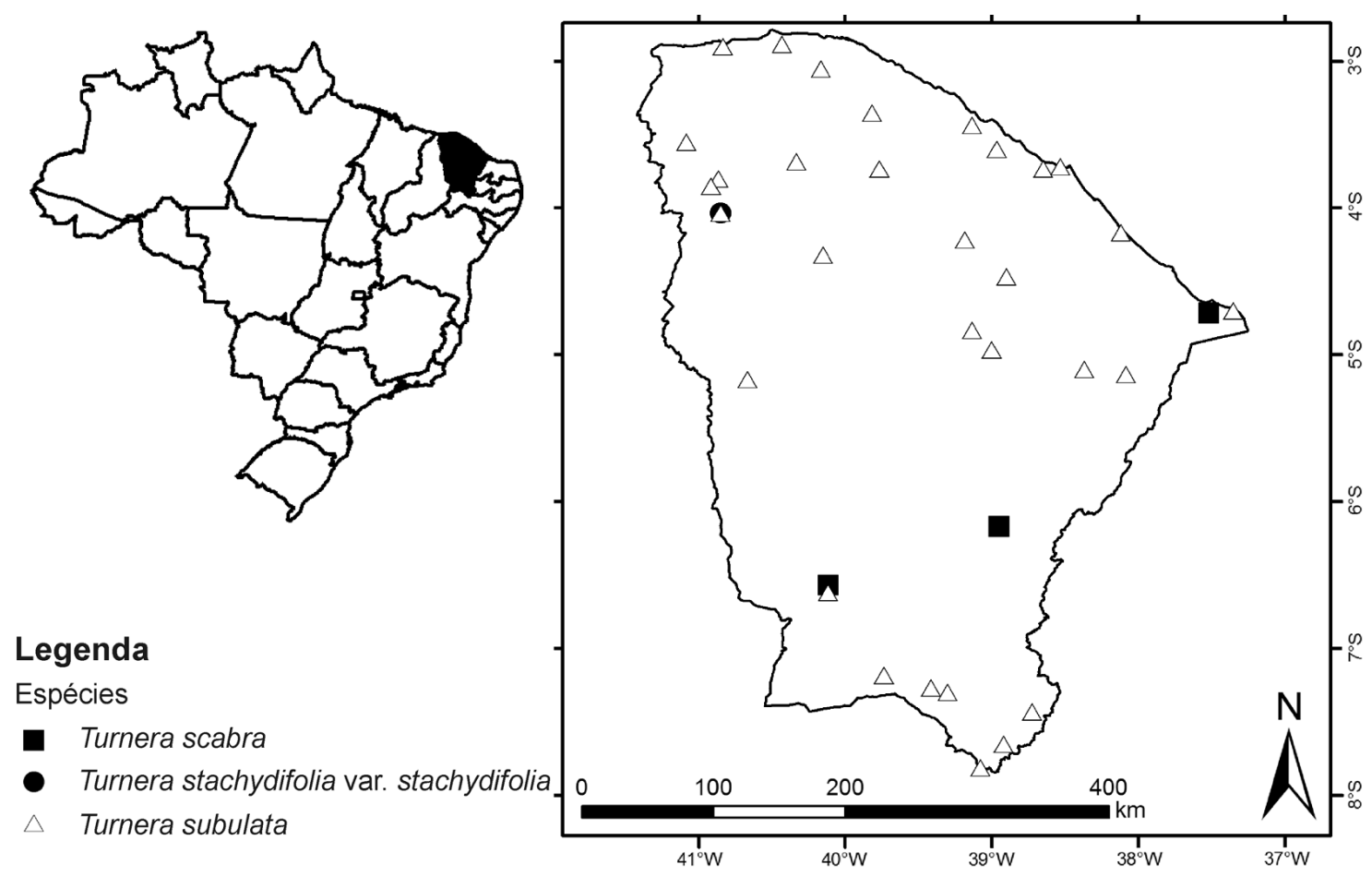

Figura 8 - Distribuição de Turnera scabra, T. stachydifolia var. stachydifolia e T. subulata no estado do Ceará. Figure 8 - Distribution of Turnera scabra, T. stachydifolia var. stachydifolia and T. subulata in Ceará state. 

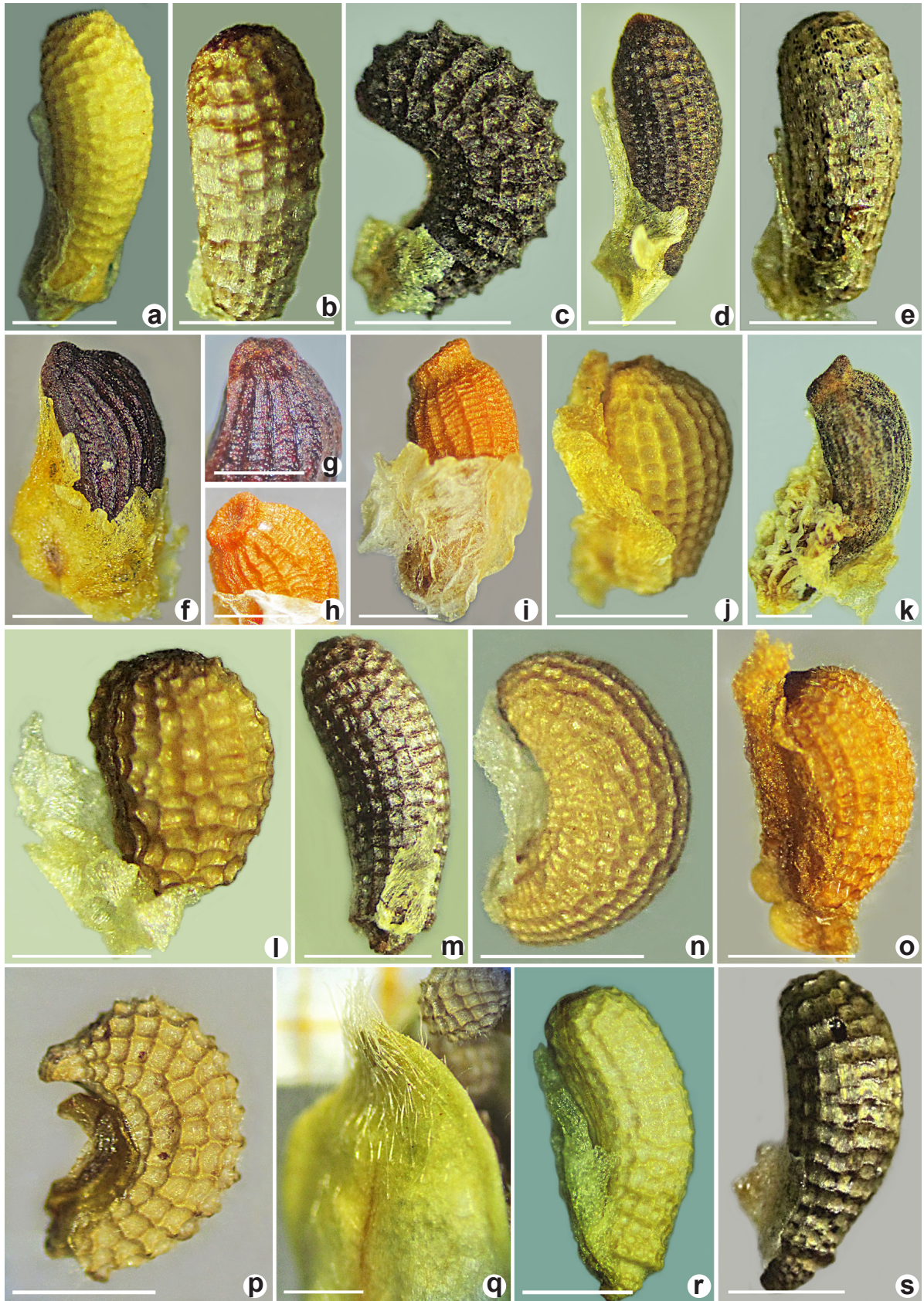

Figura 9-a. Piriqueta dentata-semente imatura; b. P. guianensis subsp. elongata-semente imatura; c. P. racemosa-semente madura; d. P. sidifolia var. multiflora-semente madura; e. $P$. viscosa subsp. viscosa-semente madura; f,g. Turnera bahiensis var. truncata - f. semente madura; g. detalhe destacando a calaza; h,i. T. blanchetiana var. blanchetiana - h. detalhe destacando a calaza; i. semente imatura; j. T. calyptrocarpa - semente imatura; k. T. cearensis - semente madura; 1. T. chamaedrifoliasemente imatura; m. T. coerulea var. coerulea - semente madura; n. T. diffusa var. diffusa-semente madura; o. T. melochioides var. melochioides - semente imatura; p,q. T. pumilea var. pumilea - p. semente imatura; q. fruto evidenciando epicarpo e indumento; r. T. scabra - semente imatura; s. T. subulata - semente imatura. (a-s: L. Rocha). Escala =1 mm.

Figure 9 - a. Piriqueta dentata - immature seed; b. P. guianensis subsp. elongata-immature seed; c. P. racemosa-mature seed; d. P. sidifolia var. multiflora - mature seed; e. P. viscosa subsp. viscosa - mature seed; f,g. Turnera bahiensis var. truncata - f. mature seed; g. detail on the chalaza; h,i. T. blanchetiana var. blanchetiana - h. detail on chalaza; i. immature seed; j. T. calyptrocarpa - immature seed; k. T. cearensis - mature seed; 1. T. chamaedrifolia - immature seed; m. T. coerulea var. coerulea - mature seed; n. T. diffusa var. diffusa-mature seed; o. T. melochioides var. melochioides - immature seed; p,q. T. pumilea var. pumilea - p. immature seed; q. fruit showing epicarp and indumentum; r. T. scabra-immature seed; s. T. subulata - immature seed. (a-s: L. Rocha). Scale $=1 \mathrm{~mm}$. 
8-12 mm compr. em flores brevistilas, 4-6 mm compr. em flores longistilas, glabros, margens 2-4 mm adnatas a unha das pétalas, formando sacos nectaríferos. Estiletes 4-5,5 mm compr. em flores brevistilas, 6-12 $\mathrm{mm}$ compr. em flores longistilas, glabros. Cápsulas 5-7 mm diâm.; epicarpo verrucoso, estrigoso. Sementes 2-2,5 × 0,8-1 mm, estreito-obovoides, ligeiramente curvas, reticuladas; epiderme lisa; calaza obtusa.

Iconografia: Arbo (2005, Fig. 56f-j: 249).

Material selecionado: Aiuaba, Estação Ecológica de Aiuaba, Volta-do-Meio, 6037'S, 407'W, 400 m, 25.II.1997, fl. e fr., L.W. Lima-Verde 456 (EAC, CTES, HUEFS). Aracatiaçu, 3`48'S, 4052'W, IX.2010, fl. e fr., R.C. Duarte 14 (HUVA). Barbalha, $20 \mathrm{~km}$ de Crato, Sítio Barreira, 7¹8'S, 39¹8'W, 22.VII.1964, fl. e fr., L. Duarte \& A. Castellanos 475 (UEC). Beberibe, Morro Branco, 410'S, 38' 'W, III.1993, fl. e fr., L.W. Lima-Verde (EAC 20151). Bela Cruz, 33'S, $40^{\circ} 10^{\prime} \mathrm{W}$, IX.2007, fl. e fr., M.D.A. Silva 07 (HUVA). Camocim, praia, 254'S, 4050'W, 19.V.2000, fl. e fr., A. Fernandes (EAC 29819). Capistrano, Fazenda Arçanga, Serra Buturité, 4²8'S, 3854'W, 27.VI.1994, fl. e fr., J.B.L.P. Medeiros (EAC 21660). Caridade, Povoado do Pendanga, 413'S, 39¹1'W, 29.III.2009, fl. e fr., A.C. Bezerra 23 (EAC). Caucaia, Parque Botânico do Ceará, 344'S, 38³9'W, 24.IV.1998, fl. e fr., E.B. Souza (EAC 26409). Choró, sertão de Quixeramobim, 450'S, 39²'W, 6.V.1997, fl. e fr., M.A. Figueiredo (EAC 25509). Crateús, Ibiapaba Sul, Mambira, 5¹0'S, 4040’W, 20.V.1997, fl. e fr., L.W. Lima-Verde (EAC 25611). Crato, FLONA do Araripe, $7^{\circ} 16^{\prime}$ 'S, $39^{\circ} 25^{\prime} \mathrm{W}, 1$.VIII.2000, fl. e fr., L.W. LimaVerde 2211 (EAC). Fortaleza, Horto Municipal Falconete Fialho, bairro Passaré, 343'S, 38³2'W, 10.IV.2015, fl. e fr., C.J.E. Vasconcelos 08 (EAC). Icapuí, APA Ponta Grossa, 442'S, 37²1'W, 8.IX.2000, fl. e fr., G. Ximenes et al. 14 (EAC). Irauçuba, Fazenda Cacimba Salgada, 344'S, 3946'W, 12.V.2000, fl. e fr., A.M.S. Bitencourt 29 (EAC). Itapipoca, 321'S, 3949’W, IX.2010, fl. e fr., R.C. Duarte 02 (HUVA). Jati, Lote 5, estrada para o açude Atalho, 7039'13"S, 3855'17'W, 688 m, 6.VIII.2011, E.V.R. Ferreira et al. 361 (CTES, HVASF). Jijoca de Jericoacoara, 253'S, 40²6'W, 26.IV.1998, fl. e fr., L.Q. Matias (EAC 27013). Limoeiro do Norte, $5^{\circ} 8^{\prime} \mathrm{S}, 38^{\circ} 5^{\prime} \mathrm{W}$, 20.V.2008, fl. e fr., L.W. Lima-Verde 3467 (EAC). Mauriti, Sítio Barreiro, 7²5'55'S, 3843'32”W, 408 m, 9.IX.2009, fl. e fr., D. Araújo et al. 832 (HVASF). Morada Nova, Baixo Jaguaribe, Fazenda Serraria, 56'S, 38²2'W, 15.IV.1997, fl. e fr., M.A. Figueiredo (EAC 25398). Paraipaba, Lagoinha, 3'26'S, 39²'W, 25.V.2003, fl. e fr., D. Ventura (EAC 32493). Penaforte, Lote 4, Sítio Baixio dos Couros, 748'45"S, 394'34"W, 496 m, 15.II.2011, fl. e fr., A.L. Alves \& W.A. Pimenta 4 (CTES, HVASF). Quixadá, horto de plantas medicinais-IFCE, 4${ }^{\circ} 58^{\prime} \mathrm{S}, 39^{\circ} 0^{\prime} \mathrm{W}, 2$.V.2013, fl. e fr., J.M. Negreiro 08 (EAC). Santa Quitéria, Fazenda Itatiaia, 4¹9'S, 409'W, 27.IV.1984, fl. e fr., A. Fernandes (EAC 12518). Santana do Cariri, Sítio Buriti, $7^{\circ} 11^{\prime} \mathrm{S}$, 3944'W, 30.XII.1981, fl. e fr., A.L. Peixoto \& O.L. Peixoto
1647 (UEC). São Benedito, 4²'S, 4051'W, IX.2007, fl. e fr., N.V. Sousa 17 (HUVA). São Gonçalo do Amarante, 3'36'S, 3858'W, 12.VII.2004, fl. e fr., D.S. Sampaio 20 (EAC 28215). Sobral, 341'S, 40²0'W, IX.2007, fl. e fr., P.V. Boa Ventura 10 (HUVA). Ubajara, caminho da Gruta de Ubajara, 351'S, 4055'W, 27.I.1968, fl. e fr., Z. Trinta 1317 (R). Viçosa do Ceará, 3³3'S, 415' 'W, IV.2007, fl. e fr., F.J. Carneiro 18 (HUVA).

Ruderal. Nas Américas, distribui-se no Panamá, Colômbia, Venezuela, Guiana Francesa, Equador, Norte da Bolívia e Brasil. Também foi encontrada na Ásia (Indonésia, Malásia, Singapura, Sri Lanca e Tailândia) e África (Madagáscar e Seicheles) (Arbo 2005). No Brasil, ocorre na maioria dos Estados, exceto Acre e Roraima (no Norte) e todos aqueles da região Sul (BFG 2015). No Ceará associa-se aos mais diversos tipos de ambientes, geralmente na caatinga, cerrado, floresta ombrófila e tabuleiros litorâneos, em áreas abertas e ensolaradas, às vezes antropizadas; cresce sobre substratos argilosos, pedregosos ou arenosos. Floresce e frutifica durante o ano todo. Pode ser reconhecida principalmente pelas flores epífilas, heterostilas, com pedúnculo adnato ao pecíolo, pétalas creme, raro amarelas, com base castanho-escura. Assemelha-se a Turnera scabra e Turnera orientalis (Urb.) Arbo; a primeira se diferencia pelas pétalas amarelas com base, às vezes, amarelo-escura; a segunda, não ocorrente no Ceará, e diferencia-se pelas flores homostilas e pétalas totalmente amarelas.

\section{Agradecimentos}

À Coordenação de Aperfeiçoamento de Pessoal de Nível Superior (CAPES), a concessão da bolsa de Doutorado a LR; a Isis Mascarenhas de Souza, a ajuda com as fotografias; a Naron Silva Tanzillo, a confecção dos mapas; a Leonardo Jales Leitão, as fotografias de T. reginae; aos curadores dos herbários citados, por viabilizarem o acesso às coleções; aos projetos INCT - Herbário Virtual da Flora e Fungos do Brasil (Processo 465.420/2014-1), Rede Integrada em Taxonomia de Plantas e Fungos - SISBIOTA BRASIL (Processo 563.342/2010-2), Efetividade de UCs Federais do estado do Ceará na conservação biológica do semiárido brasileiro - Ubajara e Aiuaba (Processo 551998/2011-3), Estrutura e funcionamento de comunidades e populações do semiárido brasileiro (Processo 552213/2011-0), o apoio financeiro para as coletas de campo. Maria Iracema Bezerra Loiola agradece ao CNPq, a bolsa de Pesquisador concedida (Processo 304099/2017-1 ). Aos revisores, editores e Dra. Maria Mercedes Arbo, as valiosas considerações para a melhoria do manuscrito. 


\section{Referências}

APG IV - Angiosperm Phylogeny Group (2016) An update of the Angiosperm Phylogeny Group classification for the orders and families of flowering plants: APG IV. Botanical Journal of the Linnean Society 181: 1-20.

Arbo MM (1977) Adenoa, nuevo género americano de Turneraceae. Hickenia 1: 87-91.

Arbo MM (1979) Revisión del género Erblichia (Turneraceae). Adansonia, sér. 2, 18: 459-482.

Arbo MM (1995) Turneraceae. Parte I. Piriqueta. Flora Neotropica 67: 1-156.

Arbo MM (1997) Estudios sistemáticos en Turnera (Turneraceae). I. Series Salicifoliae y Stenodictyae. Bonplandia 9: 151-208.

Arbo MM (2000) Estudios sistemáticos en Turnera (Turneraceae). II. Series Annulares, Capitatae, Microphyllae y Papilliferae. Bonplandia 10: 1-82.

Arbo MM (2005) Estudios sistemáticos en Turnera (Turneraceae). III. Series Anomalae y Turnera. Bonplandia 14: 115-318.

Arbo MM (2006a) Flora de Grão-Mogol, Minas Gerais: Turneraceae. Boletim de Botânica da Universidade de São Paulo 21: 1-24.

Arbo MM (2006b) Turneraceae. In: Barbosa MRV, Sothers C, Mayo S, Gamarra-Rojas CFL \& Mesquita AC (eds.). Checklist das plantas do nordeste Brasileiro: angiospermas e gymnospermas. Ministério da Ciência e Tecnologia, Brasília. Pp. 150-151.

Arbo MM (2007) Turneraceae. In: Kubitzki K, Rhower JB \& Bittrich V (eds.). The families and genera of vascular plants. Vol. 9. Springer, Heidelberg. Pp. 458-466.

Arbo MM (2008) Estudios sistemáticos en Turnera (Turneraceae). IV. Series Leiocarpae, Conciliatae y Sessilifoliae. Bonplandia 17: 107-334.

Arbo MM (2009) Turneraceae. In: Cavalcanti TB \& Batista MF (orgs.). Flora do Distrito Federal, Brasil. Vol. 7. Embrapa Recursos Genéticos e Biotecnologia, Brasília. Pp. 285-312.

Arbo MM (2013) Turneraceae. In: Prata APN, Amaral MCE, Farias MCV \& Alves MV (orgs.). Flora de Sergipe. Vol. 1. Gráfica e Editora Triunfo, Aracajú. Pp. 533-549.

Arbo MM \& Giulietti AM (2009) Turneraceae. In: Giulietti AM, Rapini A, Andrade MJG, Queiroz LP \& Silva JMC (orgs.). Plantas raras do Brasil. Conservação Internacional (CI-Brasil), Belo Horizonte. Pp. 385-390.

Arbo MM \& Mazza SM (2011) The major diversity centre for neotropical Turneraceae. Systematics and Biodiversity 9: 203-210.

Arbo MM \& Silva PH (2005) Turneraceae. In: Wanderley MGL, Shepherd GJ, Melhem TS \& Giulietti AM (coords.). Flora fanerogâmica do estado de São Paulo. Instituto de Botânica, São Paulo. Vol. 4, pp. 351-359.
Arbo MM, Gonzalez AM \& Sede SM (2015) Phylogenetic relationships within Turneraceae based on morphological characters with emphasis on seed micromorphology. Plant Systematics and Evolution 301: 1907-1926.

BFG - The Brazil Flora Group (2015) Growing knowledge: an overview of seed plant diversity in Brazil. Rodriguésia 66: 1085-1113.

Braga R (2001) Plantas do Nordeste Especialmente do Ceará. Fundação Guimarães Duque, Mossoró. $175 \mathrm{p}$.

Cabreira TN, Facco MG \& Miotto STS (2015) Piriqueta pampeana, a new species of Turneraceae (Passifloraceae s.l.) from Rio Grande do Sul, Brazil. Phytotaxa 234: 75-82.

Capistrano SHB \& Loiola MIB (2015) Flora do Ceará, Brasil: Krameriaceae. Rodriguésia 66: 905-912.

CRIA (2005) Geoloc. Disponível em < http://splink. cria.org.br/geoloc $>$. Acesso em 22 fevereiro 2017.

Cronquist A (1981) An integrated system of classification of flowering plants. The New York Botanical Garden. Columbia University Press, New York. $1261 \mathrm{p}$.

GonzálezAM \& Arbo MM (2004) Trichome complement of Turnera and Piriqueta (Turneraceae). Botanical Journal of the Linnean Society 144: 85-97.

Harris JG \& Harris MW (2000) Plant identification terminology: an illustrated glossary. Spring Lake Publishing, Utah. 216p.

Hijmans RJ, Guarino L \& Mathur P (2017) DIVA-GIS. Ver. 7.5. Disponível em <http://diva-gis.org/>. Acesso em 22 fevereiro 2017.

IPNI (continuamente atualizado) The international plant names index. Disponível em < http://www.ipni.org/ index.html>. Acesso em 22 fevereiro 2017.

Menezes MOT, Taylor NP \& Loiola MIB (2013) Flora do Ceará, Brasil: Cactaceae. Rodriguésia 64: 757-774.

Payne WW (1978) A glossary of plant hair terminology. Brittonia 30: 239-255.

Radford AE, Dickison WC, Massey JR \& Bell CR (1974) Vascular plant systematics. Harper \& Row Publishers, New York. 891p.

Rocha L \& Rapini A (2016) Flora da Bahia: Turneraceae. Sitientibus série Ciências Biológicas 15: 1-72.

Rocha L, Melo JIM \& Camacho RGV (2012) Flora do Rio Grande do Norte, Brasil: Turneraceae Kunth ex DC. Rodriguésia 63: 1085-1099.

Rocha L, Camacho RGV, Sales MF \& Melo JIM (2017) Flora da Região de Xingó, Alagoas e Sergipe (Brasil): Turneraceae. Rodriguésia 68: 569-579.

Soares-Neto RL, Cordeiro LS \& Loiola MIB (2014a) Flora do Ceará, Brasil: Combretaceae. Rodriguésia 65: 685-700.

Soares-Neto RL, Magalhães FAL, Tabosa FRS, Moro MF, Costa e Silva MB \& Loiola MIB (2014b) Flora do Ceará, Brasil: Capparaceae. Rodriguésia 65: 671-684. 
Thiers B [continuamente atualizado] Index Herbariorum: a global directory of public herbaria and associated staff. New York Botanical Garden's Virtual Herbarium. Disponível em $<$ http://sweetgum.nybg. org/science/ih/>. Acesso em 22 fevereiro 2017.

Thulin M, Razafimandimbison SG, Chafe P, Heidari N, Kool A \& Shore JS (2012) Phylogeny of the
Turneraceae clade (Passifloraceae s.l.): TransAtlantic disjunctions and two new genera in Africa. Taxon 61: 308-323.

Tokuoka T (2012) Molecular phylogenetic analysis of Passifloraceae sensu lato (Malpighiales) based on plastid and nuclear DNA sequences. Journal of Plant Reseach 125: 489-497. 